\title{
Kernos
}

Revue internationale et pluridisciplinaire de religion grecque antique

6 | 1993

Varia

\section{Epigraphic Bulletin for Greek Religion}

\section{Angelos Chaniotis}

(2) OpenEdition

Journals

\section{Electronic version}

URL: http://journals.openedition.org/kernos/557

DOI: 10.4000/kernos.557

ISSN: 2034-7871

\section{Publisher}

Centre international d'étude de la religion grecque antique

\section{Printed version}

Date of publication: 1 January 1993

Number of pages: 309-342

ISSN: 0776-3824

Electronic reference

Angelos Chaniotis, «Epigraphic Bulletin for Greek Religion », Kernos [Online], 6| 1993, Online since 07 April 2011, connection on 15 September 2020. URL : http://journals.openedition.org/kernos/557 
Kernos, 6 (1993), p. 309-342.

\section{EPIGRAPHIC BULLETIN FOR GREEK RELIGION 1989 (EBGR)}

This third issue of $E B G R$ presents the largest part of the publications of 1989 and some addenda to EBGR 1987 and 1988; due to unforeseen obligations several articles and books could not be considered in the present report and will be presented in the next issue together with the publications of 1990. The principles explained in Kernos, 4 (1991), p. 287288 apply also for this issue. In order to faciliate work with this bulletin, I have added a survey of some selected topics. The abbreviations used are those of L'Année Philologique and Supplementum Epigraphicum Graecum. I am very much obliged to M. Peachin and Michel Michalik for improving my English.

\section{Additional abbreviations}

Egitto e storia antica: L. CRISCUOLO - G. CERACI (eds.), Egitto e storia antica dall'ellenismo all'età araba. Atti del Colloquio Internazionale, Bologna 31.8.2.9.1987, Bologna 1989.

Egnatia 1:

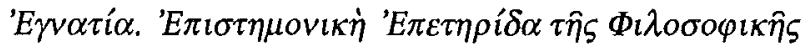

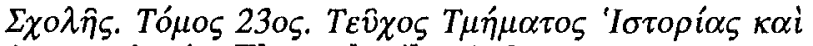

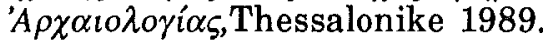

Rogozen Treasure: B.F. CoOK (ed.), The Rogozen Treasure: Papers of the Anglo-Bulgarian Conference, 12 March 1987, London 1989.

\section{Selected topics}

acclamations: 123

animals in cult: 123 ; cow 46; goat 29 ; pigeon 36.123 ; sow 91 ; possession of animals by sanctuaries: 14.46

anniversaries: $\mathbf{4 5 . 4 6}$

apparition: 31.45 .115

associations: 8.29.60.66.91.104.115

asylia: 29.48.76.89.91.115

banquet: 29

birthday: 8.91; of gods 55; of kings/emperors 8.37 .78 .86

calendar: 29.57 .70 .127

Christianity: 53

confession inscriptions: 123 
cults of cities/areas (a selection): Apollonis 115; Attaleia 115; Ephesos 55; Hierokesaireia 115; Hyrkanis 115; Kroton 41; Magnesia at Sipylos 115; Morrylos 46; Mylasa 11; Rhodos 60; Sebastopolis 66; Sicily 29; Thyateira 115; Tralleis 91; also see emperor cult, governor cult, royal cult

cult objects / paraphernalia: 3.11.14.30.33.98.115

curses: 6.8 .16 .29 .67

death: 7.21 .42 .101

dedications: 3.27 ; in fulfilment of testaments 115; of slaves 15.115; spoils 29 ; weapons 29

defixio: see curses

deities (a selection; new and rare deities, deities attested for the first time in a place, deities discussed thoroughly): Acheloos (Messene) 86; Adranos (Halaisa) 29; Amphitrite (Illyria) 59; Angelos (=Hekate?) 6. 29; Anteros (Korinth) 126; Aphrodite (Nagidos) 80; Aphrodite Euploia 72; Aphrodite Meilichia 94; Apollon Hekatombaios (Ptolemais) 116; Apollon Maleatas 86; Apollon Toumoundou 15; Artemis (Gerasa) 65; Artemis Aristoboule (Rhodos) 60; Artemis Kekoia (Rhodos) 60; Artemis Kindya (Olymos) 11; Artemis Mounichia 83; Artemis Pheraia (Syracuse) 29; Artemis Sardiane (Sardeis) 37.48; Asklepios 58 (Aquincum). 29 (Phintias); Athena Itonia 63; Athena Nikephoros (Sardeis) 48; Aura 6; Demeter (Herakleia) 88; Dionysos (Kolophon) 98; Dionysos Erikepaios (Hierokesaireia) 115; Dionysos Kathegemon 77 (Pergamon). 115 (Thyateira); Dioskouroi (Pheneos) 64; Eloros (Syracuse) 29; Ennodia (Syracuse) 29; Euploia 72; Eura (=Aura) 6; Hekate 6. 29; Hera Kourotrophos (Selinous) 30; Hera Lakinia (Kroton) 41; Herakles Leuktriades (Leuktra) 90; Herakles Soter (Chersonesos) 108; Homonoia 29 (Nakone). 52.80 (Nagidos); Isis Euploia 72; Kybele (Sardeis) 37; Leto (Olymos) 11; Ma Aniketos (Lydia) 115; Malophoros (Selinous) 29; Pan (Tralleis) 91; Pasaratos (Megara Hyblaia) 29; Poseidon (Illyria) 59; Pyretos (Hierapolis) 101; Soteira (Ikaros) 51; Sozon 107; Timassa (Syracuse) 29; Zeus Akraios (Skythopolis) 118; Zeus Genethlios (Sardeis) 37; Zeus Kouthos (Messene) 86; Zeus Larasios (Tralleis) 91; Zeus Messapios (Lakonia) 18; Zeus Orios (Tauromenion) 29; Zeus Ouranios (Gerasa) 13. Egyptian $d .:$ 8.68.72.73.75.91.95.97.104.105.111.115; Oriental $d$. : 36.37.57.104

divination: 115

dreams: 45.91

emperor cult: 8.33.35.39.44.49.55.66.75.78.86.91.101.115.120

epiphany: 47

expiation: 123 
festivals: 1.8.23.24.37.39.40.46.51.55.60.64.78.82.86.91.95.115. 120

foundation of cults: 15.20 .45 .91 .105

funerary foundations: $91 ; f$. imprecations: $11.115 .122 ; f$. rituals: 26.92.115; see also graves

games: see festivals

governor cult: 54

graves, violation of: 11.115

healing: 8.45.91.95.100.123

heroes, hero cult: 29 (Pasaratos, Pedios). 39 (Palaimon). 45 (Arcadian h.). 62 (Aulonites). 85 (Irsaios). 115 (C. Iulius Xenon)

hymns: 12

Jews: 22.47

illness: 25.29; as punishment: 123

impurity: 123

incense: 14

inventories: see sanctuaries

invocations: 8.10 .22 .36 .73

laurel: 14

leges sacrae: 29.45 .60 .91 .96

magic: 10.25 .103

manumission: 15.110

miracles: 45.47

months: see calendar

mysteries: 55.77.86.91.115.127

names, theophoric: 8.53 .124 ; herophoric: 23 ; related to religion 16 (Thytes). 115 (Sakerdotianos)

neokoreia of cities: 55.91

oath: 43

oikistes: 29

oracles: 91.95 .97 .100 .113

Orphism: 21.34.42.69.71.102.109.115

phylacteries: 10.25 .103

pilgrimage: 8.111

Platonism: 36

politics and religion: 105.127

priests: 16; families of: 4.55.78.91.115; for life-time: 35.45.91.95.115; accumulation of offices: 60.115 ; other cult officials: agonothetes 23.55.60.84.86.91.93.115; amphipolos 29; archistolestes 8; herald 14.60; hierokeryx 16.55; hieroparektes 16; hieropolos 29.70; hieromnemon 29.91; hieronomos 96.115; hierophantes 115; hierophylax 29; hierosalpistes 16; hierothytes 29; mantis 16; neokoros 115; neopoios 14.55; panegyriarchos 55.115 ; prophetes 8.11 .60 .115 ; prostates 8.29 .86 ; pyrphoros 75.86 ; spondaules 16 ; thyepolos 79 
processions: 33.37

proskynema see pilgrimage

prostitution (temple p.): 15.91

purification: 60

rebirth: 42

river gods: 29.86

royal cult: 8.33 .37 .38 .45 .52 .55 .77 .80 .81 .91 .115

sacrifice: 8.11 .14 .29 .45 .91 .98 .121

sacrilege: 8 (?).114.123

sanctuaries: administration: 3.8 .14 ; control by a city: 39 ; finances: 14.29.55.91.112.115; inventories of: 3.30 .115 .117 ; privileges: 8.37.48.89.115; property of: 55.115; loans made by: 29.112.123; jurisdiction in: 113.123; relocation of: 51 ; slaves of: 15.91

soul: 29.45.115.122

suicide: 11

supplication: 31.48 .60

syncretism: 8.33 .36 .73 .111 .123

theoria, theoros: 91.98

Thracian rider god: 62.85

water: 10.68 .95

women: 103 ; association of: 29 ; fertility of: 95

\section{Greek words}

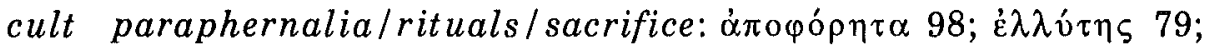

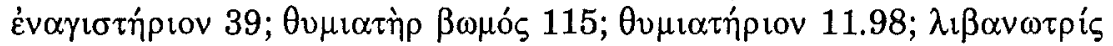

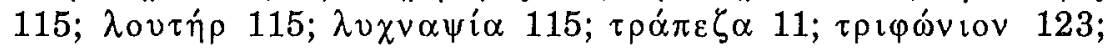

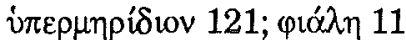

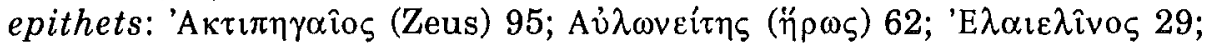

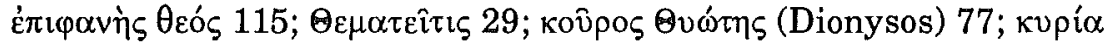

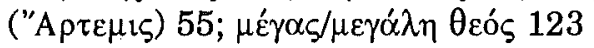

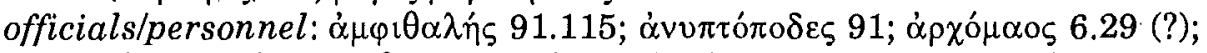

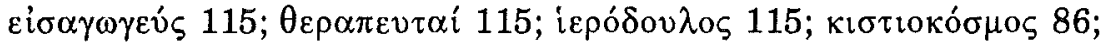

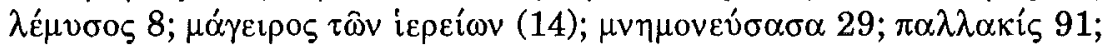

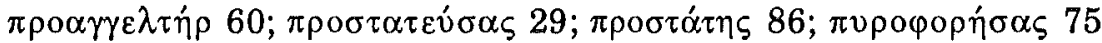
(cf. 86)

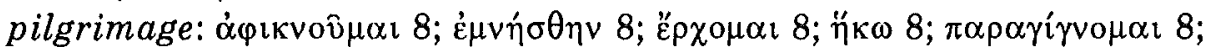
$\theta \alpha v \mu \alpha \dot{\zeta} \zeta \infty$

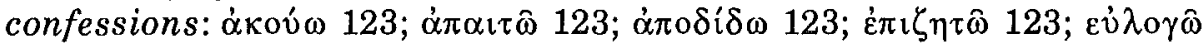
$123 ; \varepsilon \dot{\chi} \chi \alpha \rho \imath \tau \hat{\omega} 123 ; \kappa \circ \lambda \alpha \dot{\zeta} \omega 123 ; \sigma \tau \eta \lambda \circ \gamma \rho \alpha \varphi \hat{\omega} 123$

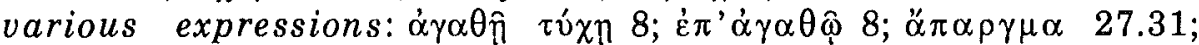

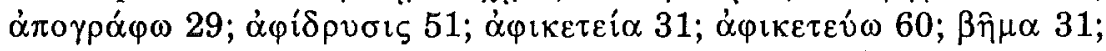

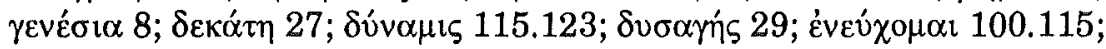

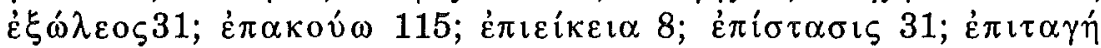

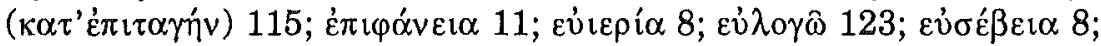




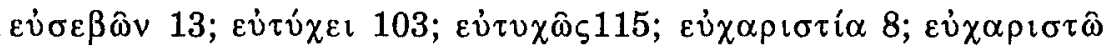

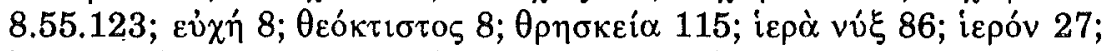

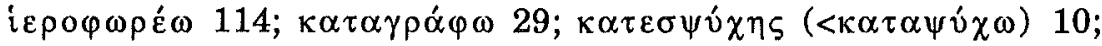

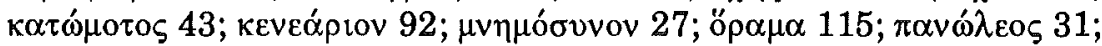

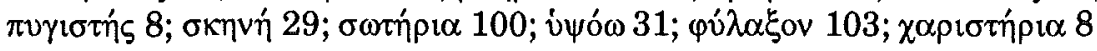

1) $A D, 38 \mathrm{~B} 1$ (1983) [1989], p. 83: Mention of a boundary stone, probably of the sacred place, where the visitors of the Nemea gathered during the festival (Nemea, 4th c. BC).

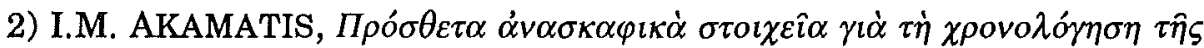

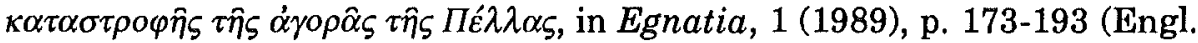
summary) [BE 1990, 463; $S E G 38,645]$ : Ed. pr. of a fragmentary inscription, possibly a dedication to Dionysos (Pella, early 4th $\mathrm{c}$. BC).

3) S.B. AlEShIRE, The Athenian Asklepieion: The People, Their Dedications, and the Inventories, Amsterdam 1989 [SEG 38, 118]: A.'s book on the Athenian Asklepieion cannot be presented here analytically. It offers a valuable study of numerous subjects, such as the history, topography, and administration of the sanctuary, the dedications, the sociology of the people that participated in the cult, and also provides a list of the priests of Asklepios. The epigraphic part of the book (103-369) includes the nine inventories concerning the dedications and cult objects of the Asklepieion (no new texts, but some new restorations, translations, and excellent commentaries).

4) M. ALEXANDRESCU-VIANU, Notes de prosopographie histrienne: La famille d'Hippolochos, fils de Théodotos, in Mélanges Pierre Lévêque. Vol. 3. Anthropologie et société, Besançon 1989, p. 1-5 [SEG 38, 738]: Reconstruction of the stemma of a distinguished family of Histria (5th-4th c.), whose members held the eponymous priesthood of Apollon Ietros, dedicated statues of Apollon and Leto, and donated a propylon [see already EBGR 1988, 3].

5) W. AMELING, Das neue attische Dekret für Oropos. Ein Datierungsvorschlag, in $Z P E, 77$ (1989), p. 95-96 [BE 1990, 221]: A. dates the inscription EBGR 1987, 59 to 294/92 BC. [But see now M.B. WaLBANK, in The Athenian Agora. Vol. XIX, Princeton 1991, p. 189 who prefers a date close to $338 \mathrm{BC}$ ].

6) R. ARENA, Iscrizioni greche arcaiche di Sicilia e Magna Grecia. Iscrizioni di Sicilia. I. Iscrizioni di Megara Iblea e Selinunte, Milano 1989: Corpus of the archaic inscriptions from Megara Hyblaia and Selinous. Since the corpus of DuboIs [infra (29)] includes most of these texts (sometimes with better readings, restorations, and commentaries) I give here only the concordances between the two corpora and note several important differences: Megara Hyblaia: $12 \mathrm{~A}=25 \mathrm{D} ; 13 \mathrm{~A}=20 \mathrm{D}$ [SEG 38, 945; A. interprets $\dot{\alpha} \rho \chi \chi^{\prime} \mu \alpha 0 \varsigma$ as a cult official]. Selinous: 35 A=84 D; 36 A=51 D; 37 A=52 D; 38 A=55 D [A. accepts the reading $[\tau \hat{\alpha}]_{\imath}$

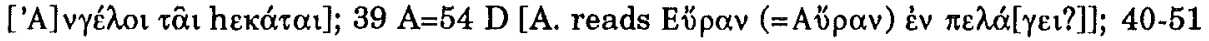
$\mathrm{A}=41-50 \mathrm{D}$ (dedications to Meilichios); $53 \mathrm{~A}=78 \mathrm{D} ; 75 \mathrm{~A}=90 \mathrm{D} ; 77 \mathrm{~A}=134 \mathrm{D}$; defixiones: $59 \mathrm{~A}=29 \mathrm{D}$ [D. offers new readings], $60 \mathrm{~A}=31 \mathrm{D}, 61 \mathrm{~A}=37 \mathrm{D}, 62 \mathrm{~A}=30 \mathrm{D}$, 
$63 \mathrm{~A}=38 \mathrm{D}, 64 \mathrm{~A}=35 \mathrm{D}, 66 \mathrm{~A}=32 \mathrm{D}, 67 \mathrm{~A}=33 \mathrm{D}$ [D. offers new readings], $69 \mathrm{~A}=36 \mathrm{D}$, $70 \mathrm{~A}=34 \mathrm{D}, 71 \mathrm{~A}=39 \mathrm{D}$; A.'s corpus includes a judicial defixio (65) and a fragmentary text (68) not included in the corpus of D. A's commentaries concern almost exclusively linguistic questions.

7) M.W. BALDWIN BOWSKY, Epigrams from Lato pros Kamara (Crete), in Hesperia, 58 (1989), p. 115-129: Ed. pr. of a funerary epigram for a magistrate, whose death is described with the words $\dot{\omega} \varsigma \delta \varepsilon$ il $\tau \dot{\alpha} \sigma \tau \grave{\eta} \rho \quad \lambda \dot{\alpha} \mu \psi \alpha \varsigma$

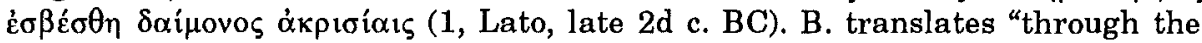
imprudence of his daimon". [Rather "through the unfair judgment of a divine power": see E. VouTIRAS, A funerary epigram from Latos in Crete, in Hesperia, 59 (1990), p. 670 note 6; cf. K.J. RIGSBY, Two Cretan Epitaphs, in ZPE, 83 (1990), p. 237-239: "by the caprices of fortune". RIGSBY offers a persuasive restoration of the epigram].

8) A. BERNAND, De Thèbes à Syène, Paris 1989: Corpus of the Greek inscriptions from the valley between Luxor and Assouan. The few new texts are marked with an asterisk. Tuphium: Two honorific decrees of the priests' synod for Ptolemaios III and Ptolemaios IV (1.2); $\mathrm{n}^{\circ} 1$ mentions festivals, panygereis, and the birthday of the king; from $n^{\circ} 2$ only a fragment with the titles of the king is preserved. Hermonthis: Dedication to Hermes and Herakles in honour of a strategos; this honour was probably decreed by the ephebes or an association of graduates of the gymnasium (5, hell.). Pathyris: A dedication to Isis Thea Megiste of Pathyris (6, imp.) and several proskynemata (7-10, imp.); $n^{\circ} 7$ mentions Anubis, $\mathrm{n}^{\circ} 10$ is dedicated to Priotos Theos Megistos, Horegebthis, Isis Resakemis (of southern Egypt?) and their synnaoi. Isis' epitheton is a hapax. Latopolis: $N^{\circ} 12$ records the dedication of a statue of an epistrategos, which took place on the birthday $(\gamma \varepsilon \vee \varepsilon \in \sigma \alpha)$ of the honoured person, in the month Hadrianos, or [more probably] on the birthday of Hadrian ( $y \in v \varepsilon \sigma_{1 \alpha} \alpha$ 'A $\delta$ pıvôิ); dedications to Ammon (13) and Isis (20, imp.); a series of proskynemata (14-18, imp.) naming kyrios Ammon (14) and Ammon (15.18). Eileithyiaspolis: A decree of the priests' synod at Kanopos for Ptolemaios III, Berenike II, and their daughter Berenike (37, 238 BC); the preserved lines concern the dedication of a statue of the younger Berenike. A series of proskynemata $\left(23.26 .33\right.$, imp.); $n^{\circ} 23$ with the expression $\ddot{\eta} \kappa \omega \pi \alpha \rho \alpha$ is dedicated to Smithis. [ $\mathrm{N}^{\circ} 31-32$ with the expression $\ddot{\eta} \kappa \omega$ could be proskynemata; however, this expression can occur in a profane context as well, e.g. in $\mathbf{n}^{\circ} 35$ ].

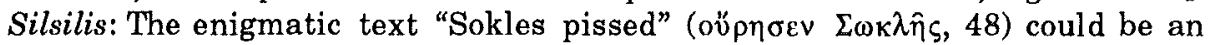
"inscription sacrilège", i.e. a parody of prohibitions to urinate on tombs or in holy places, but B. does not exclude the possibility that Sokles recorded his healing from a pathological impediment to urinate. The graffito $\tau \delta^{\prime} \delta$ '

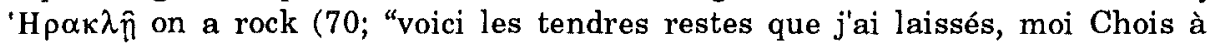
Hérakles") is probably an epitaph. A malediction with the expression "ै̌ $\xi_{\omega}$ was written by Petechnumis, who calls himself a $\pi v \gamma \sigma \tau \tau \dot{\eta}(110$, paedicator $) . N^{\circ} 174$ records the construction of a sanctuary of Souchos and the dedication of a statue of

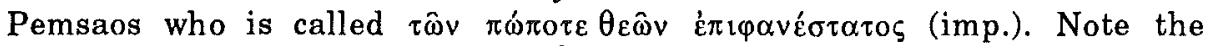

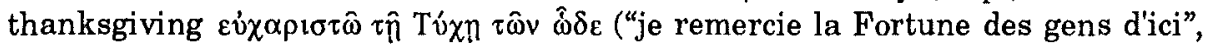
141, imp.), two vows (47.52), dedications to Isis Thea Megiste (83, cf. 168, imp.), and numerous proskynemata (68.79.85.86.95.97,98.*99bis.101.103-106.108.109. 111.114.115-122.124-127.129.130.135.142.160.162.164.165-167.171.175, hell. and imp.); the following dieties are mentioned: Ammon (175), Isis Thea Megiste (164), 
Zeus-Nephotes Megistos (171); the ankh-cross is engraved on two proskynemata

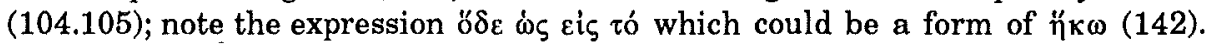

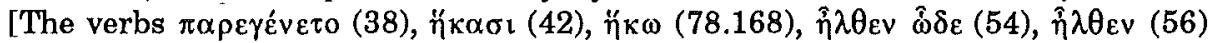
could also imply proskynemata; cf. supra]. Officials (imp.): a priest (140), $\lambda \varepsilon \dot{\varepsilon} \mu \sigma \sigma o$ (priests) of Souchos (174), prostatai of Ammon (136.139), an architect in the service of Ammon (107), a $\mu \eta \kappa \alpha v \alpha ́ p l o \varsigma$ (engineer) in the service of Isis (159). Ombos: Dedications to: Aroeris Theos Megas Apollon and his synnaoi (of a $\sigma \eta \kappa o ́ \varsigma$ by soldiers, hell., 188), Ptolemaios VIII, Kleopatra III, Souchos Theos Megistos, and their synnaoi (190), Apollon Theos Megistos and his synnaoi (192, imp.), Aphrodite Thea Megiste (of a sanctuary, imp., 193), Sarapis Theos Megistos Polieus (195, imp.), Apollon, Souchos, and their synnaoi (197); $\mathrm{n}^{\circ} 194$ was dedicated for the salvation of Caracalla and Iulia Domna; a series of proskynemata (199.200.*

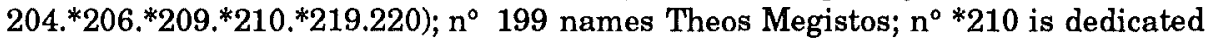
to Kyrios Ammon and Souchos; the expression $\dot{\varepsilon} \lambda \theta \dot{\omega} v \dot{\varepsilon} \theta \alpha v ́ \mu \alpha \sigma \alpha$ could also imply a proskynema (221). Syene: A dedication to a king Ptolemaios (*225) and two proskynemata (232.234, imp.); ${ }^{\circ} 232$ names Isis. Elephantine: A copy of the Greek text of the Rosetta stone with the decree of the priests' synod for Ptolemaios V (241, $196 \mathrm{BC})$. An interesting dossier of letters of Kleopatra III and Ptolemaios IX concerns the privileges and the administration of the sanctuary of Chnoum (244,

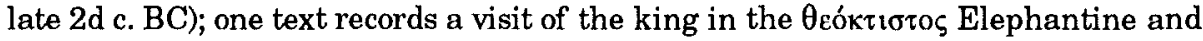
describes the sacrifices and rituals performed on this occasion $(244, \mathrm{I})$. The design of a horned animal, with the text $\dot{\varepsilon}[0] \hat{n}[\theta] \varepsilon \sigma \varepsilon \dot{\varepsilon} \mu[o i$ ?], could be a representation of Chnoum (266). Dedications to: Ptolemaios VI, Kleopatra II, their children, Chnoub, Hera, Anoukis, and Dionysos (242), Kleopatra II, Ptolemaios VIII, Kleopatra III, their children, Chnoub, Hera, Anoukis, and Dionysos (243), Chnoub, Hera, Anoukis, Isis, Dionysos, and their synnaoi (246, hell.), Ammon Theos Megistos (255), Chnoub (256), Hera Thea Megiste (250, imp). A series of proskynemata (245.253. 254.264.267-270.272-274.279-281.283.285-291.298.300, imp.); $\mathrm{n}^{\circ} 245$ with the expression $\dddot{\eta} \kappa \omega$ is dedicated to Isis; $n^{\circ} 277$ names Neilammon and his synnaoi (imp.); $n^{\circ} 272$ has the expression $\dot{\varepsilon} \mu v \eta \dot{\eta} \theta \eta$. [N 294 with the expression $\hat{\eta} \lambda \theta \varepsilon$ could also be a proskynema]. Satis: A dedication to Ptolemaios VI, Kleopatra II, their children, Ammon, Chnoub, Hera/Satis, Hestia/Anoukis, Dionysos/Petempamentis, and their synnaoi in honour of the archisomatophylax and strategos Boethos (302); the dedication was decreed at Setis by a synod of priests with the participation of the prophet of Chnoub and archistolistes of the sanctuary at Elephantine, as well as of the other priests of the fifth class (pentaphylia), i.e. the priests of Chnoum Nebieb and all the living and deceased kings of the dynasty. A dedication to Chnoub, Ammon, Satis/Hera, Anoukis/Hestia, Petempamentis/Dionysos, Petensetis/Kronos, Petensenis/Hermes, and the other demons of the Katarraktai for Ptolemaios VI and Kleopatra II was made by an archisomatophylax and the association of basilistai after a session on the holy island of Dionysos, Setis (303); the association, presided over by a prostates and a priest, financed the sacrifices and libations on the 9 th day of each month and on the other eponymous days (303). Bigeh: Two proskynemata (305.306, imp.), one of them addressed to Isis of Philai. Philai: B. publishes here only inscriptions not included in I.Philai. Dedications to: Kyria Isis (328-330), Isis, Sarapis, Harpokrates, Ammon, called Theoi Soteres, for the salvation of the elephants (309), Ptolemaios V, Kleopatra I, and Isis (314), Ptolemaios VIII, Kleopatra III, Isis Thea Megiste of Abaton and Philai, Sarapis, Harpokrates, 
Anubis, Ammon-Chnoum, and Harensnouphis (315.316), Ptolemaios VIII, Kleopatra II, Kleopatra III, Isis, Serapis, Horos, and the gods of Abaton and Philai (318), Ptolemaios VIII, Kleopatra II, Kleopatra III, Isis, Serapis, Horos, and the gods of Abaton (320), Chnoub, Isis, Hera, Athena, and the gods of Abaton (319, for Ptolemaios VIII, Kleopatra II, and Kleopatra III); a dedication for Ptolemaios IV, Berenike II, and Arsinoe III (307). Proskynemata (308.310.324.325.336, hell. and imp.); the following deities are mentioned: Isis and An- (Anoukis or Anoubis, 308), Isis and Apollon (310), Isis and the gods of Abaton (324); note the expressions $\ddot{\eta} \kappa \omega$

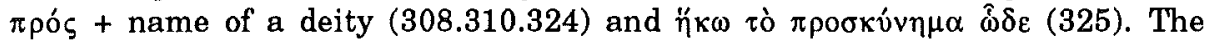

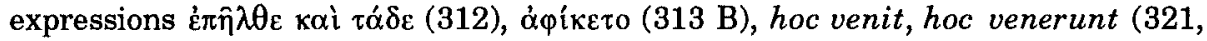
hell.), and veni (323) also imply proskynemata. [The graffito $\mathrm{n}^{\circ} 337$ could be

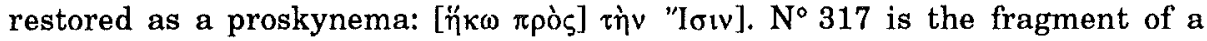
request made by the priests and the inhabitants of Philai (hell.).

Note also the personal names Herakles (11, Pathyris, imp.), Isis (Eileithyiaspolis, 26), and Serapis (Silsilis, 172), the invocation $\dot{\alpha} \gamma \alpha \theta \hat{\eta} \tau \dot{v} \chi \eta$ (19), and the expressions

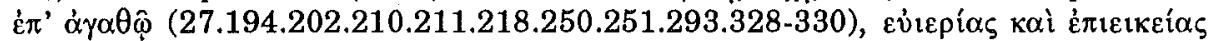

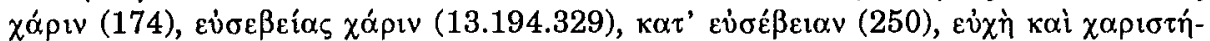

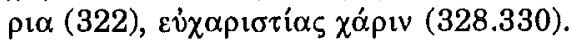

9) É. BERNAND, Les inscriptions grecques et latines d'Akôris, in Egitto e storia antica, p. 251-259 [BE 1990, 823]: Review of the epigraphic material from Akoris [see now $E B G R$ 1988, 13].

10) G. BEVILACQUA, Un filatterio gnostico inedito dai codici di Girolamo Amati, in MGR, 14 (1989), 287-298: Ed. pr. of a silver gnostic phylactery (4th c. $\mathrm{AD}$, Christian) with invocations (Iao, Sabaoth, Phre, Semesilam, Arsenophre) and common magical formulas (sequence of vowels, the palindromic

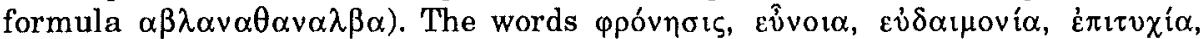

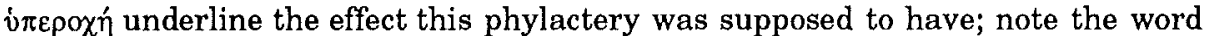
$\kappa \alpha \tau \varepsilon \sigma \psi \dot{v} \chi \eta \varsigma$ ( $<\kappa \alpha \tau \alpha \psi v \dot{\chi}(\omega)$ ), which implies the positive aspect of cold water.

11) W. BLÜMEL, Neue Inschriften aus der Region von Mylasa (1988) mit Nachträgen zu I.K. 34-35, in EA, 13 (1989), p. 1-15 [BE 1990, 21]: New inscriptions from the region of Mylasa (imp.) [cf. $E B G R$ 1988, 19]. Mylasa: A priest of Zeus Labraundos and Asklepios, and a stephenephoros (351); the epitaph of an athlete who committed suicide (496). Olymos: A dossier (895-897, late $2 \mathrm{~d}$ c. BC) concerns the construction of a temple for Leto, whose cult is for the first time attested here; in view of the great $\varepsilon \pi 1 \varphi \alpha$ 'veı $\alpha 1$ of Leto, Apollon, and Artemis the priest of the Agathoi Daimones proposed the construction of the cult statue and the temple, the dedication of various cult objects (trapeza, altar, thymiaterion, phiale)

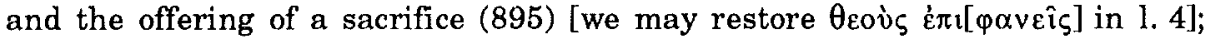
another decree orders the publication of a list of donors (896; cf. the list itself: 897). Also note the mention of a prophetes in $n^{\circ} 898$. Two new grave inscriptions from the region of Mylasa (Kzyaka, Bargylia, imp.) provide for a fine, payable to Artemis Kindya, in case of any violation of the grave (pp. 10-12) [for the payment of such fines to sanctuaries cf. $E B G R$ 1988, 52]. B. points out (p. 14) that the expression $\dot{\alpha} \varphi$ ' 'H $\rho \alpha \kappa \lambda$ éov $\zeta$ in I.Mylasa 5541.3 means that the starting point of a running contest was a statue of Herakles. 
12) S. BONEFAS, The musical inscription from Epidauros, in Hesperia, 58 (1989), p. 51-62: B. discusses the new hymn to Apollon and the Muses with signs of musical notation (Epidauros; $S E G$ 30,390); the new text is part of the hymn $I G I^{2} 1,135$, which mentions various members of Asklepios' family (Iaso, Akeso, Hygeia), Apollon Maleatas, and Asklepios. According to B.'s interpretation the inscription included two columns with hymns to Asklepios (1st column), Apollon and Asklepios (or Apollon Mousagetes and Apollon Maleatas, 2d column).

13) Z. BORKOWSKI, Inscriptions on altars from the hippodrome of Gerasa, in Syria, 66 (1989), p. 79-83: Ed. pr. of four altars found in the hippodrome of Gerasa (imp.). Two of them are dedicated to Zeus Ouranios (1, first attestation in Gerasa) and Zeus Soter (2); two of the altars were dedicated for the salvation of the emperors (1.4). Note the participle $\varepsilon \dot{v} \sigma \varepsilon \beta \hat{\omega} v$ in the dedicatory formula of $n^{\circ} 2$.

14) J. BOUSQUET, Corpus des inscriptions de Delphes. Tome II. Les comptes du quatrième et du troisième sicèle, Paris 1989 [BE 1990, 11; SEG $38,409]$ : This valuable corpus includes the accounts of naopoioi, prytaneis, and treasurers in Delphi as well as other related documents (a decree of the amphictiony concerning the appointment of naopoioi, documents related to the fine of the Phocians, lists of naopoioi etc., 4th and $3 \mathrm{~d}$ c.). The new edition and restoration of and commentary on these texts facilitates any future study of the building activities in the sanctuary of Apollon and offers a significant contribution to our knowledge of the financial administration of the sanctuary and the amphictiony. The accounts of the 4 th c. recording the contributions of cities and individuals to the sanctuary (1-30) provide information on the origin, sex, and occupations of the donors. Some practical aspects of the administration are demonstrated by an account of the works carried out on the occasion of the Pythia (139, 247/46?), further through accounts of the expenses for the supply of laurel (34.46.50.55.56.62), incense (46.50.55.62), kerykeia (76.101), for the construction of barriers in front of the hearth and the tripod ( $49 \mathrm{~B})$, for the carrying out of the statues of Phocian leaders (34), and by the accounts of the pay for the cooks of

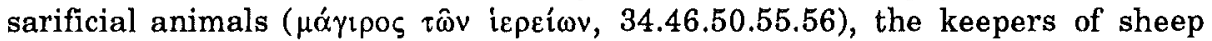
(34.46.50.55), and the heralds (31.34.35.46.49.55.56.62.76.84.87.97.102.107.109.110.1 13.125.128.131).

15) C. BRIXHE - A. PANAYOTOU - R. HODOT - M. BILE, Bulletin épigraphique. Asie Mineure, in REG, 102 (1989), p. 438-467: Critical remarks to various epigraphic publications. The dedication of 6 slaves (Hierokaisareia, $2 \mathrm{~d}$ c. BC, $S E G 35,1155$ ) could be a manumission and not a testimony of temple

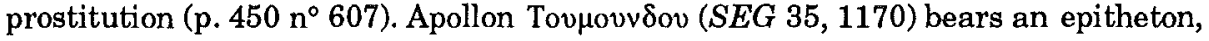
which derives from the name of the cult founder (p. $452 \mathrm{n}^{\circ} 628$ ) [cf. infra (20)].

16) M. BUONOCORE, Regio III. Lucania et Bruttii, Regium Iulium, in Supplementa Italica $V$, Roma 1989, p. 29-84: This survey of the epigraphic material from Forum Iulium includes a usefull review of the cult officials (p. 35, 4546). Among the recent epigraphical finds note two lists of officials (manteis, hierokerykes, hierosalpistai, hieroparektai, spondaulai: $12-13,1$ st c. $A D$ ), and a defixio addressed to Pluton and Kore (37). B. argues that the word Ovins in IG XIV 617 is a personal name (p. 45). 
17) K. BURASELIS, Review of: T. RIZAKIS - G. TOURATSOGLOU,

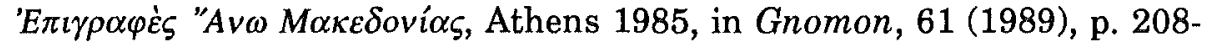
211: B. restores in I.Mac I 29 the personal name Mama or Mamia [whereas M.B. HATZOPOULOS had restored the name of the godess Ma: cf. EBGR 1987, 45; 1988, 167].

18) R.W.V. CATLING - D.G.J. SHIPLEY, Messapian Zeus: An Early Sixth-Century Inscribed Cup from Lakonia, in ABSA, 84 (1989), p. 187200: Ed. pr. of a metric graffito on a cup (early 6th c. BC). The name of Zeus Messapios can be recognized in this fragmentary inscription. His cult, already

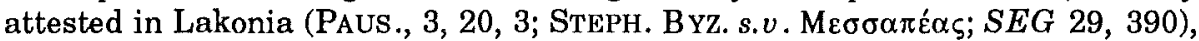
probably came from South Italy. The location of the shrine (or shrines) of Zeus Messapios still remains a matter of speculation.

19) A. CHRYSOSTOMOU, in $A D, 38$ B2 (1983) [1989], p. 301-302: Mention of a dedication of a Herakles statue in the gymnasion of Edessa (3d c. AD).

20) T. CORSTEN, Attu kome, in $Z P E, 77$ (1989), p. 181-184: C. discusses a

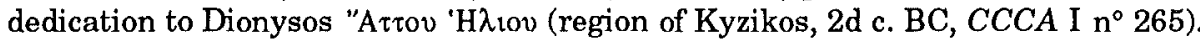
The two genitives had been interpreted as filiations, Dionysos being the son of Attis and Helios. C. recognizes here an epitheton of Dionysos, which derives from the name of the cult founder (Attis Helios); he points out that there is an Attou kome near Kyzikos. [But M. Cremer, Bewaffneter Dionysos, in MDAI (I), 38 (1988),

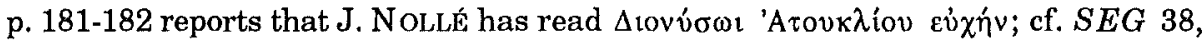
1262].

21) D.M. COSI, L'orfico fulminato, in MusPat, 5 (1987), p. 217-231:

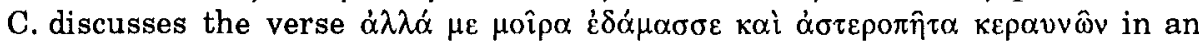
Orphic leaf from Thurioi and comments on the ancient beliefs concerning the death of persons who had been struck by a lightning.

22) H.M. CoTTON - J. GEIGER, Masada II. The Yigael Yadin Excavations 1963-1965. Final Reports. The Latin and Greek Documents, Jerusalem 1989: Ed. pr. of a graffito with the inscription 'A $\alpha \alpha$ in Tú $x \eta(930,1$ st c. $\mathrm{AD}$ ). C.-G. reject a pagan association and point out that numerous Jewish names are composita of Tyche. [But this cannot exclude the attribition of the graffito to a pagan inhabitant of Masada].

23) J.J. COULTON - N.P. MILNER - A.T. REYES, Balboura Survey: Onesimos and Meleager. Part II, in AS, 39 (1989), p. 41-62 [BE 1990, 113]: Ed. pr. of the building inscription of an exhedra donated by Meleagros (1, Balboura, ca. AD 130-160) [cf. EBGR 1988, 34]. The text refers to Melagros as the "perpetual agonothetes of the foremost quadrennial festival of the Antoninia Meleagria". He and his ancestors bear "herophoric" names (Meleagros, Kastor, Polydeukes).

24) N.B. CROWTHER, The Sebastan games in Naples (IvOl. 56), in ZPE, 79 (1989), p. 100-102 [BE 1990, 253]: New readings in an inscription concerning the organisation of the festival Sebasta in Neapolis (IvO 56) imply that the upper limit for the games for boys was the 17th (not the 16th) year of age; the prize was the same for all the age divisions (a crown of wheat). 
25) R.W. DANIEL - F. MALTOMINI, Una gemma magica contro l'infiammazione dell'ugola, in ZPE, 78 (1989), p. 93-94 [BE 1990, 154]: Reedition of an inscribed gem (2d/3d c.) with the word $\sigma \tau \alpha \varphi \nu \lambda \dot{\eta}$ written eight times, each time with one letter less; thus the text has the form of a grape. The word $\sigma \tau \alpha \varphi v \lambda \eta$ means uvula; the gem was an amulet against the inflammation of the uvula.

26) J.W. DAY, Rituals in stone: Early Greek grave epigrams and monuments, in JHS, 109 (1989), p. 16-28: In a general study of archaic Greek grave epigrams D. discusses their relation to funerary rituals. Several epigrams mention the construction of the tomb and echo the ritual lament; when read loud they become a song of praise for the dead. D. argues that epitaphs memorialized the funerary rites to passers-by who had no opportunity to attend them.

27) A. DI VITA, Atti della Scuola 1985, in ASAA, 63 (1985) [1989], p. 337376: Mention of vases with graffiti, dedicated to the Kabeiroi (telesterion in Lemnos, cl.; p. 340, 342, fig. 6). About 200 graffiti on vases dedicated to Athena Ialysia (6th-4th c., p. 368-369, 371 fig. 53) have been found in Ialysos; they bear

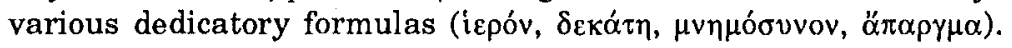

28) C. DOBIAS-LALLOU, Bulletin épigraphique. Cyrénä̈que et Afrique Mineure, in $R E G, 102$ (1989), p. 473-477: New readings in SECir 114 b:

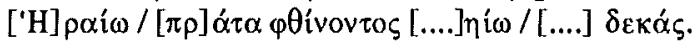

29) L. DUBOIS, Inscriptions grecques dialectales de Sicile, Rome 1989 [BE 1990, 858]: Corpus of the dialect inscriptions of Sicilian states found in Sicily and abroad. The corpus includes no new texts, but many new readings, restorations and excellent commentaries [cf. the corpus of ARENA, supra (6)]. All texts are BC. Zankle/Messene: Dedications of war booty to Zeus Olympios in Olympia (4-5, 5th c.). Himera: A metric dedication to Athena with the citation of h.Hom. 12, 3 (8, 6th c.), a sling stone dedicated (?) to Zeus Soter (13, 5th c.). Megara Hyblaia: D. offers a new interpretation of the archaic lex sacra (20, early 6 th $\mathrm{c}$.) concerning a sacrifice [SEG 26, 1084; cf. EBGR 1988, 62]. The document concerns a sacrifice to the hero Pasaratos; any person who sacrifices during the month Archomaos (a word previously interpetated as an office) should pay the eighth part. Selinous: Numerous defixiones (29-40, 6th-late 5 th c.); they usually name

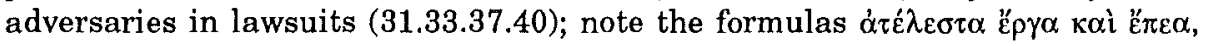

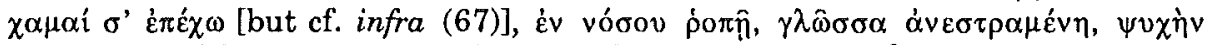

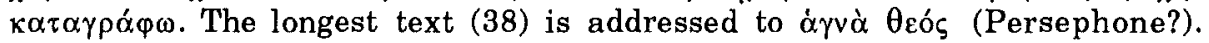
Dedications to: Zeus Meilichios (41-50; found in the sanctuary of Malophoros, 6th5 th c.), Apollon Paian and Athena (51, 5 th c.), Apollon (52, 5th c.), Hera (56, 3d c.), Herakles (84, early 6th c.), Hekate and Angelos (55, 5th c.) [cf. supra (6)], Zeus (53, 5 th c.), and Malophoros $(54,5$ th c.); in the last dedication D. reads ev่ $\chi \dot{\alpha} v$ ENחE $\Lambda A[-$

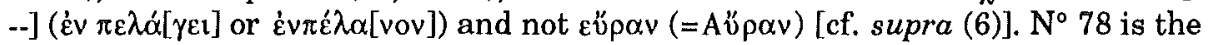
well known inscription from the temple $G$ naming the gods who gave victory to the Selinountians (ca. 450). Syracuse: Graffiti on vases dedicated to Herakles (90, 5th c.), Artemis Pheraia=Ennodia (92, late 4th c.), and Asklepios (102) [=EBGR 1988, 42], the signature of an artist at the temple of Apollon (86, early 6th c.), an altar for the river Eloros and the nymph Timassa (101, 3d c.), and a dedication to Hera and

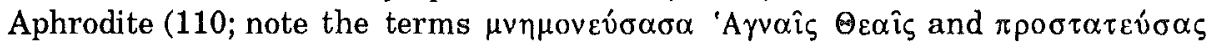




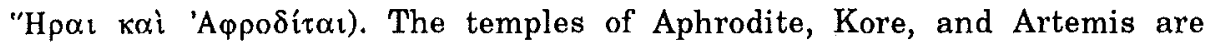
mentioned in $n^{\circ} 109$ (hell.). The documents found abroad include dedications in Delphi (93) and Olympia (94-95) as well as a letter concerning the recognition of the asylia of Magnesia on the Maiander (97). Kamarina: Defixiones (118-123, 5th-

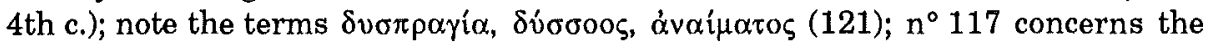
recognition of the asylia of the Asklepieion at Kos (3d c.). Gela: Apart from dedications found in Olympia (132) and Delphi (133) the Geloan inscriptions include an imprecation ( $\left.\varepsilon \dot{v} \times \eta^{\prime}\right)$ concerning a love affair $(134 \mathrm{~b}$, note the terms

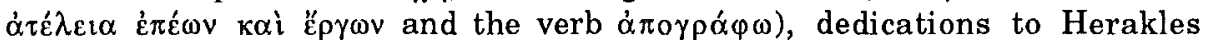
(159.168a, 4th/3d c.), graffiti on vases dedicated to Antiphamos, the Rhodian oikistes $(135,6$ th $/ 5$ th c.), Athena $(139$, ca. 500 BC), Hera $(137.138,6$ th-5th c.), Herakles $(162,6$ th c.), and Thesmophoros=Demeter $(155,6$ th c.); the last text was dedicated by an association of women participating in sacred banquets ( $\sigma \kappa \eta v \alpha \hat{i})$ under the leadership of Dikaio; $\mathrm{cf}$. $\mathrm{n}^{\circ} 164$ mentioning a private cult association $\left(\theta \varepsilon \sigma \tau \alpha_{1}\right)[=E B G R 1988,42]$. The offices of hieropolos and hieromnemon are mentioned in $\mathrm{n}^{\circ} 160-161 ; \mathrm{n}^{\circ} 160$ concerns the recognition of the asylia of the Asklepieion at Kos (242 BC); this text attests the existence of an Asklepieion in Phintias. $\mathrm{N}^{\circ} 177$ (SEG 27,657) is an enigmatic and probably badly copied text mentioning the debts of some persons to a goddess (previously interpreted as a contract between a sanctuary and a collector of taxes). Two dedications to the hero Pedios (17, ca. $500 \mathrm{BC}$ ) may be attributed to the area of Gela. Akragas: Dedications to Hermes (183) and to Apollon on Delphi (182 a-b); a hierothytes (185). Tauromenion: A document concerning the foundation of a gymnasion dedicated to Hermes and Herakles $(187,2 d \mathrm{c}$.) and the protection of icpòv $\chi \rho \hat{\eta} \mu \alpha$; note the term

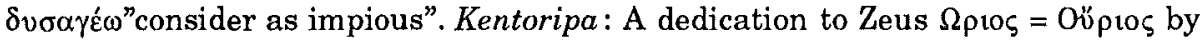
an amphipolos (188) [but see EBGR 1987, 3: $\left.\Omega \rho{ }_{10}=" \Omega p r o \varsigma\right]$. Morgantina: Apart from the dedication of vases to 'E $\lambda$ are $\lambda$ ivos $(190,4$ th $c$.) and Dionysos $(191,4$ th $c$.), note three enigmatic inscriptions, perhaps citations from comedies (193, hell.); one

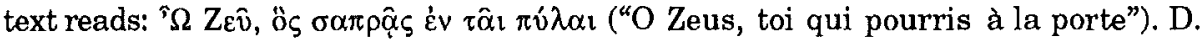
mentions ten defixiones addressed to Ge, Hermes, Persephone, Pluton, and the Theoi Katachthonioi (195, hell.). Halaisa: Reedition of the long cadastral register (196, 2d c.), which mentions the sanctuaries of Zeus Meilichios (I 16), Apollon (II

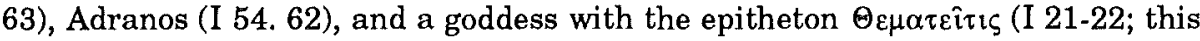
was previously interpreted as the name of a fountain or a route). D. translates the passage referring to an olive-grove as follows: "Pourtour : appartient à l'oliveraie tout olivier sacré qui s'y trouve" [cf. EBGR 1988, 152]. Henna: An association of Demetriastai (198, 3d c.). Entella: Reedition of the decrees which mention the eponymous office of a hieromnemon, a sanctuary of Hestia, and the months Eumenideios, Euergeios, and Panamos (204.206-212, ca. 300). Nakone: The reconciliation decree $(205$, ca. $300 \mathrm{BC})$ prescribes the mingling of the adversaries in a civil strife in new families. The creation of new family bonds was sealed by the sacrifice of a white goat; a yearly sacrifice to Homonoia and the ancestors should remind of this event. The text also mentions the month Adonios and a sanctuary of Zeus Olympios. Segesta: A dedication to Aphrodite Ourania (213, hell.). The offices of hierothytes, hieromnemon, and hierophylakes are mentioned in $n^{\circ} 215-216$. 
30) L. DUBoIS, Bulletin épigraphique. Espagne, Italie, Sicile, in $R E G$, 102 (1989), p. 477-481: Critical remarks to various texts. An inscription with a list of cult objects found near Taras [EBGR 1987, 65] is not a dedication but an inventory of cult objects delivered by potters and smiths (p. 478 no. 846 ). A vase with the inscription EPA found in Selinous [Sicilia Archeologica, 19 (1986), p. 52-53] is probably a dedication to Hera Kourotrophos, whose cult is attested there (p. 481, $\mathrm{n}^{\circ} 837$ ).

31) L. DUBOIS, Bulletin épigraphique. Mots nouveaux et mots rares, in $R E G, 112$ (1989), p. 408-410: I note the words or terms connected with res sacrae:

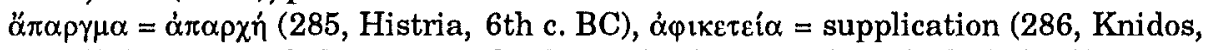
$3 \mathrm{~d}$ c. BC), $\beta \hat{\eta} \mu \alpha=$ dedication in the form of a footprint (287, Delos), $\dot{\varepsilon} \gamma \kappa \alpha \dot{\alpha} \nu \mu \mu \alpha=$ case for dedicated earrings (293, Didyma, 2d c. BC) [EBGR 1988, 63], غ́ $\xi \dot{\alpha} \rho \varepsilon o v=$ court of a cryptoporticus surrounding a temple for the emperor cult (296), $\dot{\varepsilon} \xi \omega \dot{\omega} \lambda \varepsilon 0 \varsigma$ $=\dot{\varepsilon} \xi \dot{\omega} \hat{\lambda} \eta \zeta$ (297, Mylasa, imp.), $\dot{\varepsilon} \pi \dot{i} \sigma \tau \alpha \sigma i \varsigma=$ apparition of a god or a hero (according

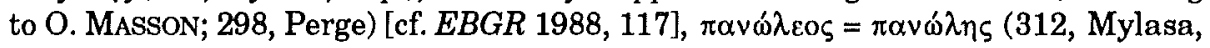
imp.), juó $=$ to exalt a god (327, Lydia imp.).

32) H. ENGELMANN - D. KNIBBE, Das Zollgesetz der Provinz Asia. Eine neue Inschrift aus Ephesos, in EA, 14 (1989), p. 1-206: The new document about the customs of the province Asia prohibits the installation of customs houses on the land of sanctuaries or in other sacred domains (ll. 31, 71-72, p. 74, 93).

33) D. FISHWICK, Statue taxes in Roman Egypt, in Historia, 38 (1989), p. 335-347: F. studies a group of ostraka concerning the imposition of a special tax for the provision or restoration of imperial statues. Through a study of hell. inscriptions F. shows that the living Ptolemies did not receive a cult as ovvvoor in temples of other deities; such a cult is attested only for deceased kings. In view of this material S. argues that in imperial times this levy supported the provision not of cult images, as generally believed, but of statues of emperors intended to be set in temples as offerings or transported in processions as cult objects. The statue tax supported the continuation of rites which reach back into Pharaonic Egypt.

34) A. FOL, The royal inscriptions on the silver vessels from Rogozen, in Rogozen Treasure, p. 33-37: General presentation of the 16 Greek inscriptions on the silver vessels from Rogozen (4th c.) [cf. $E B G R 1988,119$ ]. $F$. argues that the letters I and $\Delta$ on a vessel with the name of king Satokos are numerals (10 and 4), which "designate the essence of the cosmological model of Thracian Orphic religion" and belong to the royal insignia (cf. A. FoL, Trakiiskiyat

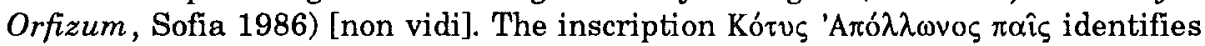
the Odrysian king as son of Apollon; Apollon, the Sun, was believed to have joined the Great Mother Goddess Kotyto.

35) S. FOLLET, Bulletin épigraphique. Attique, in REG, 102 (1989), p. 422-427: $I G \mathrm{II}^{2} 1992$ which mentions a high priest of Nero and Zeus Eleutherios has to be dated ca. $\mathrm{AD} 61$ and not ca. 67-68 (as suggested by RosivacH); Nero was worshipped together with Zeus Eleutherios, whereas later emperors were

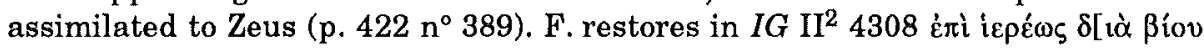

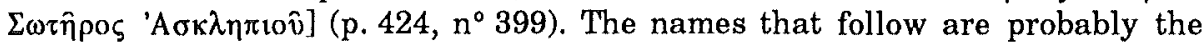
names of cult officials [SEG 38, 186]. 
36) P.-L. GATIER - A.-M. VÉRILHAC, Les colombes de Déméter à Philadelphie-Amman, in Syria, 66 (1989), p. 337-348: Edition of two epigrams [already published by L. DI SEGNI: see $E B G R$ 1988, 163; the eds. did not know the ed. pr.]. According to G.-V. the two epigrams were written on a funerary columbarium erected near a sanctuary of Zeus [DI SEGNI regarded the text as a single dedicatory epigram]. The text refers to the pigeons as fertilisers and thus as nourisers of Demeter (earth). G.-V. offer a thorough literary analysis and improve

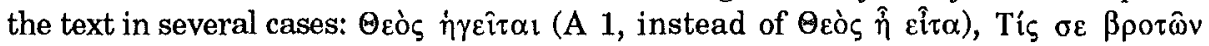

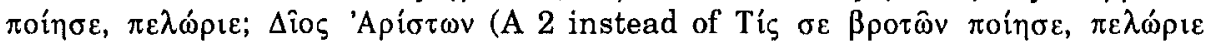

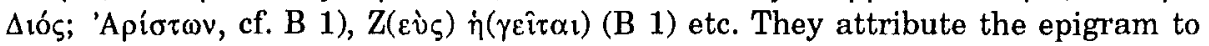
Philadelpheia (Amman) and comment on the cult of Demeter and Zeus (Atragatis-

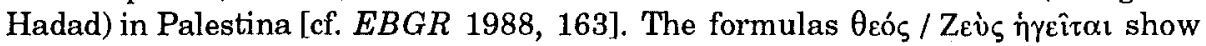
Platonic influence. A funerary inscription erected by the same person and found near the columbarium permits an exact date ( $A D$ 139/40); this epitaph begins with an invocation of Agathe Tyche and Zeus Soter.

37) Ph. GAUTHIER, Nouvelles inscriptions de Sardes II, Genève 1989 [BE 1990, 20]: Ed. pr. of inscriptions found in Sardeis. $N^{\circ} 2$ is a dossier published in a temple in the Metroon. It includes a letter of the queen Laodike (213 BC), with which she accepts the honours bestowed on her by Sardeis, i.e. the foundation of a temenos (Laodikeion, see p. 61 note 39 for other parallels), an altar, a yearly panegyris (Laodikeia) on the 15 th of Hyperberetaios, a procession, and a sacrifice to Zeus Genethlios for the royal family. G. offers a thorough commentary, esp. on the Metroon, the cult of Meter Theon/Kybele (p. 54-58), and the various attestations of cults of Laodike (61-78). The new text confirms that Artemis and Kybele had separate cults in Sardeis. The honours for Laodike provide us with the earliest attestation of her cult (also known in Teos in 204/3 and Iasos in 195); the Laodikeia probably lasted several days, but the ceremonies for Laodike were performed on one day, probably the birthday of the queen. Zeus Genethlios received a sacrifice as protector of the family. $\mathrm{N}^{\circ} 3$ is a letter of Antiochos III (213 BC) granting an exemption from taxes for three days during the Laodikeia. G. also comments on the commercial aspects of hellenistic festivals.

38) P. GAUTHIER, Bulletin épigraphique. Institutions, in REG 102 (1989), p. 390-408: G. comments (p. 402-403 $\mathrm{n}^{\circ}$ 276) on the new letter of Antiochos III to Zeuxis [EBGR 1987,67] and doubts that Dion had the same duties under Antiochos II as Nikanor, high priest for the dynastic cult and in charge of the sanctuaries. It is possible that Dion had held only the second offfice.

39) D.J. GEAGAN, The Isthmian dossier of $P$. Licinius Priscus Juventinianus, in Hesperia, 58 (1989), p. 349-360 [BE 1990, 103]: G. reconstructs a dossier of texts (partially unpublished) recording the benefactions of P. Licinius Priscus Juventinianus, high priest of the provincial emperor cult and agoranomos of the Isthmian games, for the sanctuary of Poseidon (ca. AD 170/180). The constructions offered to the sanctuary included quarters for the athletes, the shrine of Palaimon, an $\dot{\varepsilon} v \alpha \gamma$ iorńprov for a chthonic cult, altars of the ancestral gods, a temple of Helios, Demeter, Kore, Dionysos, and Artemis; Priscus also financed the restoration of the temples of Eueteria, Kore, and Pluton. G. discusses the topography of the sanctuary, the financial aspects of the donation, 
the involvement of the proconsul, and the legal rights of the city as regards the festival.

40) D. GERGOVA, The find from Rogozen and one religious feast in the Thracian lands, in Klio, 71 (1989), p. 36-50 [BE 1990, 166]: G. suggests that the treasure of inscribed silver vases found in Rogozen [cf. EBGR 1988, 119, supra (34), and infra (50)] is connected with the cult of the Hyperborean triad (Earth, Moon, Sun); the vases had been symbolically buried during a festival. G. connects the phiale with a representation of Auge and Herakles and the inscription АYГH $\triangle \mathrm{H} \Lambda \mathrm{A} \Delta \mathrm{H}$ with Delos [but see infra (50)] and interprets the name Kotys as the name of the mother goddess [There is hardly anything in this article, which is not mere speculation].

41) M. GIANGIULO, Ricerche su Crotone arcaica, Pisa 1989: General study of the archaic period of Kroton, including a discussion of the local cults and their epigraphic documentation (p. 51-96); G. studies especially the cults of Hera Lakinia (p. 54-79) and Apollon (p. 79-92) and discusses the relations of Kroton to Olympia (p. 99-130) and Delphi (p. 131-160).

42) M. GIGANTE, Dall'aldilà orfico a Catullo, in PP, 44 (1989), p. 26-29: Discussion of the new Orphic leaves from Thessaly [cf. $E B G R$ 1987, 112 and infra (69) and (71)]. G. underlines the idea of rebirth after death expressed in these texts

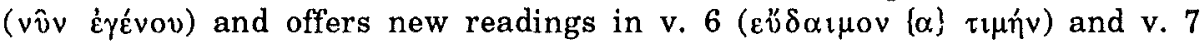

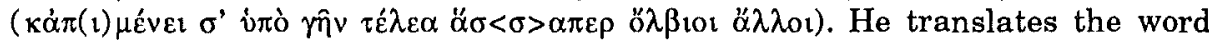
$\tau \varepsilon ́ \lambda \varepsilon \alpha$ in 1.7 as "premi, ricompense"; an allusion to this Orphic formula can be recognized in CATULL., 76, 5-6 (multa parata manent tum in longa aetate...gaudia).

43) A.J. GRAHAM - R.A. SMITH, An elipse in the Thasian decree about delation (ML 83)?, in AJPh, 110 (1989), p. 405-412 [BE 1990, 235]:

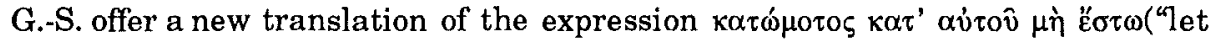
him not be under oath against himself") in a Thasian decree encouraging delation of revolutionary plots (ca. $410 \mathrm{BC}$ ). "The informer was freed from the oath he gave to his fellow conspirators, calling down annihilation on himself and his family if he should betray the plot".

44) W. GÜNTHER, $Z u$ den Anfängen des Kaiserkultes in Milet, in $M D A I$ (I), 39 (1989), p. 173-178: Ed. pr. of an honorary inscription for the

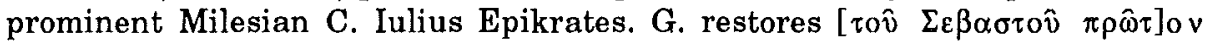
$\dot{\alpha} \rho \chi\left\llcorner\varepsilon \rho \varepsilon \alpha \gamma \gamma \varepsilon v{ }^{\prime} \mu \varepsilon v o[v]\right.$ and suggests that Epikrates was the founder of the emperor cult in Milet.

45) P.A. HANSEN, Carmina epigraphica Graeca saeculi IV a. Chr. $n$. (CEG 2), Berlin-New York 1989: It is not possible to present here analytically the second volume of H.'s valuable corpus of Greek epigrams, which includes only already published texts (but often with new restorations) of the 4 th $\mathrm{c}$. BC. Important for the student of religion are especially the dedicatory epigrams (742889), addressed to various deities. Dedications from Athens to: Antigonos and Demetrios Soteres (777), Aphrodite Pandemos (775), Apollon (751), Apollon Paian (742), Artemis (754.784), Artemis Agrotera (770), Asklepios (763-765.769.776), Asklepios and Hygeia (755.766), Athena (742.756.760), Athena Ergane Polias (759.774), Pallas Athena (762), Dionysos (773), Hermes and the Nymphs (743), Hermes, the Nymphs, and Acheloos (753), Kephisos (744). Dedications from other 
places to: Aphrodite Paphia (Paphos: 871.873), Aphrodite (Amathous: 872), Apollon (Argos: 816; Olympia: 830; Delphi: 787.795.798.824.831.832,877.878; Pantikapaion: 885; Paros: 842 ; Lesbos: 875 ; Kyzikos: 881 ; Xanthos: 888 ; Kydonia: 846 ; Olus: 848 ; Golgoi: 868), Artemis (Argos: 816; Paros: 843; Xanthos: 889; Kydonia: 846), Artemis Agrotera (Paphos: 870), Artemis Orthia (Sparta: 821), Asklepios (Aigina: 808; Epidauros: 818; Lisos: 847), Athena (Halikarnassos: 867; Pergamon: 876), Athena Poliouchos (Erythrai: 857), Eileithyia (Kea: 840; Astypalaia: 863), Eirene and Enyalios (Kyrenaika: 851), Ge (Tenos: 841), Hera (Argos: 812.813; Samos: 853), Herakles (Sparta: 822; Amphipolis: 879), Hermes (Histiaia: 785), Hermes Agoraios (Imbros: 845), Kastor and Polydeukes (Sparta: 819), Leto (Kydonia: 846), the Muses (Larisa: 797), Poseidon (Korinth: 809.810; Elateia: 807; Lesbos: 875), Tanos (Egypt: 874), Zeus (Olympia: 833; Delphi: 798; Pharsalos: 792; Samos: 852). Also note a graffito on a vase dedicated to Herakles (Emporion: 898).

I select some interesting phenomena: a metric lex sacra from Argos concerning a commemorative sacrifice to Apollon and Artemis after the expulsion of a tyrant (816), a lex sacra concerning sacrifices to Asklepios (847, Lisos), the foundation of Asklepios' cult in Athens (763), the foundation of the cult of Demeter and Kore in Knidos after a dream (860), the report of a dream which lead to the foundation of the cult of Demeter and Kore (Priene, 854), epigrams of thanks for cures (Asklepios: 755.776; Herakles: 822), the report of a miracle (Delphi: 894), the genealogy of the Arkadian heroes (824), a priestess of Athena, who served for 64 years (757), the appearance of Athena in a dream (795). Among the grave epigrams I note several texts expressing thoughts about the immortality of the soul

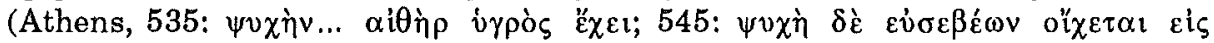

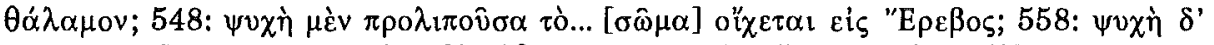

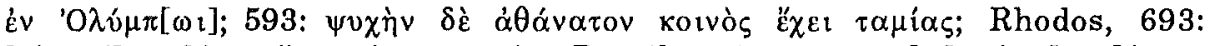

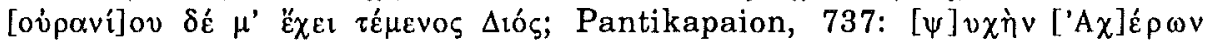

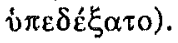

46) M.B. HATzOPOULOS - L.D. LoUKOPOULOU, Morrylos, cité de la Crestonie, Athènes 1989 [SEG 38,604]: Collection of the inscriptions of Morrylos (Macedonia); new texts are marked with an asterisk. The most interesting texts are two honorific decrees $\left({ }^{*} 1 .^{*} 2,3 \mathrm{~d} / 2 \mathrm{~d} \mathrm{c}\right.$.) set up in the Asklepieion for benefactors who had donated to Asklepios and the city cows as sacrificial animals; one of the cows (1) had produced in 15 years a very rich offspring. The anniversary of the election of the second benefactor (2) to the highest offices of his city in the month Daisios is declared as icpó. In the Asklepieion, the most important sanctuary of Morrylos, were found a dedication to Asklepios and Hygeia (5, 1st c. $\mathrm{AD})$ and a dedication by several persons in fulfillment of a vow $(6$, hell).

47) M. HELTZER, The Persepolis documents, the Lindos Chronicle, and the Book of Judith, in PP, 44 (1989), p. 81-101: Discussion of the first epiphany of Athena described in the "Lindos Chronicle" [FgrHist 532; Lindos 2]. In view of the new tablets from Persepolis H. dates the siege of Lindos by Datis and the rain miracle of Athena in ca. 497 BC. Some topoi common in the "Lindos Chronicle", Herodotus, and the Book of Judith (dated by $\mathrm{H}$. in the 4th c. BC) reveal literary contacts between the Greeks and the Jews of the Persian Empire. 
48) P. HERRMANN, Rom und die Asylie griechischer Heiligtümer. Eine Urkunde des Dictators Caesar aus Sardeis, in Chiron, 19 (1989), p. 127-164: Ed. pr. of a boundary stone of the sanctuary of Artemis Sardiane (Sardeis, 1st c. BC) with texts which documented the asylia of the sanctuary (a letter of $\mathrm{M}$. Antonius and a decree of Caesar, $44 \mathrm{BC}$ ). Caesar granted the privilege of asylia to the sanctuary of Artemis on the same terms as the grant of asylia to the sanctuary of Artemis in Ephesos and the temple of Athena Nikephoros in Sardeis. This text is the first certain attestation that the temple of Athena Nikephoros was in Sardeis; this temple was recognized as $v^{\prime} \xi_{\text {}} \mu \circ \varsigma_{\text {, }}$ i.e. a shelter of suppliants. The last fragmentary lines of the new inscription mention a sanctuary of the Nymphs and the gods Zeus Megistos and Apollon. $H$. assumes that analogous grants of asylia had been made for these sanctuaries too. $H$. also offers a general discussion of Rome's recognition of the asylia of sanctuaries in Asia Minor.

49) P. HERRMANN, Ein Tempel für Caligula in Milet?, in MDAI (I), 39 (1989), p. 191-196: H. supports the historicity of CASsIUS Dio's $(59,28,1)$ account of Caligula's demand that the Apollon temple which was being built in Didyma should be dedicated to him. This temple of Caligula, dedicated to him by the province Asia, is the one mentioned in I.Didyma 107 and 148.

P. HERRMANN, see infra (115).

50) J. HIND, The inscriptions on the silver phialai and jug from Rogozen, in Rogozen Treasure, p. 38-43 [BE 1990, 164]: Discussion of the bowl with a relief of Herakles and Auge from Rogozen [cf. $E B G R$ 1988, 119, supra (40)]. The letters $\Delta \mathrm{H} \Lambda \mathrm{A} \Delta \mathrm{H}$ should not be interpretd as a Thracian or Mysian name, but as a comment on the representation of Herakles: "it is obvious, who it is" ( $\delta \eta \eta \alpha$

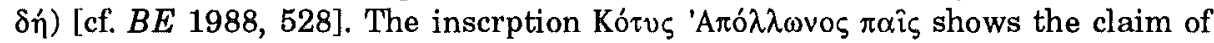
the Odrysian king to be an offspring of Apollon.

51) K. JEPPESEN, Ikaros. The Hellenistic Settlements. Vol. 3. The Sacred Enclosure in the Early Hellenistic Period. With an Appendix on Epigraphical Finds, Aarhus 1989 [SEG 38, 1546.1548]: J. reedits and discusses the inscriptions from Ikaros (Failaka, Arabian Gulf, p. 82-118). He gives many new readings and restorations of the known inscription which concerns the settlement on Ikaros, the sanctuary of Soteira, and athletic games [cf. EBGR 1988, 145]. J. identifies Ikadion, the sender of the letter concerning the settlers of Ikaros, with a person who played a role in the events around Seleukos' II accession to the throne in $246 \mathrm{BC}$ and dates the inscription to 241/240. The most important restorations are the following: In 1. 10-11 J. reads $\dot{\alpha} \varphi \hat{i} \delta[\rho v] \sigma i[v] i \varepsilon \rho \hat{\omega} \sigma \alpha 1$; the forefathers of Seleukos had consecrated a shrine or a sacred enclosure (cf. the previous restorations: $[\beta \omega \mu \circ v] \varsigma, \ddot{\alpha}[\sigma v \lambda l] \circ v, \dot{\alpha}[\gamma] \rho \circ[\hat{v}] \varsigma)$. The relocation of the sanctuary of Soteira, mentioned in this letter, was part of the royal foundation. In 11. 23-24 J. restores ov่ k[owñ]

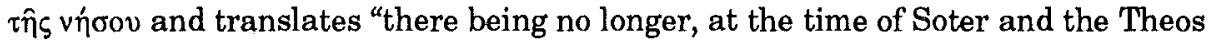
a common hearth in service on the island" [the restoration hardly makes any sense, and víбov cannot possibly be translated as "on the island"]. J. also comments on a fragmentary inscription which records the dedication of an altar to the gods by

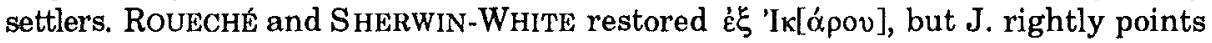

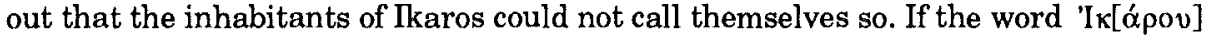


should be restored here, it probably meant settlers from the homonymous island of the Aegean.

52) C.P. JONES - C. HABICHT, A hellenistic inscription from Arsinoe, in Phoenix, 43 (1989), p. 317-346: J.-H. give an improved text of the letter of Thraseas to Arsinoe and the decree of Nagidos concerning its relations to Arsinoe [infra (80)]. They date the foundation of Arsinoe in the $260 \mathrm{~s}$ and these documents in the 230s. They also comment on the cult of Ptolemaios II and Arsinoe II in the two cities and rightly point out that the cult of Homonoia already existed in Nagidos and was not established with this decree.

53) I. KAJANTO, Sopravvivenza dei nomi teoforici nell'età Cristiana, in AArchHung, 41 (1989), 159-168: K. offers an excellent study on the theophoric names in Rome. A comparison of the theophoric names attested in ICUR, CIL VI, and IGUR shows that pagan theophoric names survived into the Christian era, even if their popularity decreased. Christians gave to their children pagan theophoric names following the common hereditary praxis. Names deriving from Iuppiter, Mars, Mercurius, Saturn, and Venus were adopted by Christians, since they could be explained as refering to planets; names deriving from Herakles (e.g. Herakleios) owed their popularity to the fact that this hero represented the virtuous man. Also the names of Christian martyrs (e.g. Dionysios, Hermes, Saturninus etc.) contributed to the survival of pagan theophoric names.

54) M. KAJAVA, Cornelia and Taurus at Thespiae, in ZPE, 79 (1989), p. 139-149 [BE 1990, 227]: K. restores IG VII 1854 (Thespiai) as a honorary inscription for the wife of T. Statilius Taurus and collects the epigraphical testimony for Taurus' cult.

55) D. KNIBBE - H. ENGELMANN - B. IPLIKÇIOGLU, Neue Inschriften aus Ephesos, in JÖAI, 59 (1989) Beiblatt, p. 164-238: Ed. pr. and short discussion of inscriptions found in Ephesos. Dedications to: Hadrian as Zeus Olympios (2), Apollon (42), Apollon Patroos (38), Eukleia (39), Artemis (40, note the

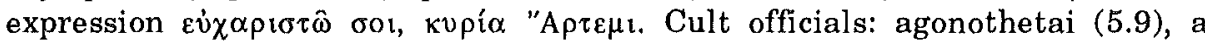
hierokeryx of Artemis (6), naopoioi (17-20.27.30.32.40.66.68), a panegyriarchos of the Pasithea (9), priestesses of Artemis (8.37.67), priests of an unknown deity (41) and Dea Roma (1, 1st c. AD), high priests of the city (37 h) and the provincial emperor cult (3.7); note that a family provided three generations of neopoioi (40). Festivals: Pasithea (9), Great Dionysia (17); the mysteries performed by the hierokeryx of Artemis (6, cf. 48) and the prytanis (14). $\mathrm{N}^{\circ} 6$ was dedicated by a hierokeryx who had introduced for the first time olive-oil distributions each month,

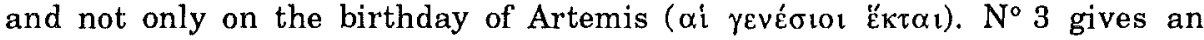
interesting insight into the rivalry between the cities of Asia Minor with regard to the title of neokoros. After Caracalla had given to Ephesos the title of neokoros of Artemis (I.Ephesos 212), Ephesos recorded in an inscription (3) its claim to be the first city which had ever received the title of neokoros thrice (twice neokoros of the emperor cult, once neokoros of Artemis); however, this claim had to be erased from this inscription later ( $\tau$ pi $\zeta$ has been changed into $\delta i \zeta$ ), probably after a protest of other cities. A decree ( $\mathrm{n}^{\circ} 37 \mathrm{~h}$; part of I.Ephesos 1687, 1st c. AD) provides for the deposition of money in the bank of Artemis (Artemis Ktesie). The vineyards of

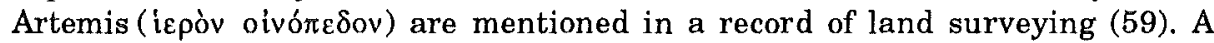
fragmentary inscription names the deified Eumenes II (65). Note two corrections to 
previously published texts: The letters $\triangle \mathrm{IKAI}$ - in a dedication to Ptolemaios, Arsinoe, and Sarapis (I.Ephesos 199) do not belong to an epitheton of Sarapis, but to the name of the dedicant (p. 235); $S E G 32,942$ is not a dedication to Eumenes, but to Ptolemaios, Arsinoe, and the Theoi Soteres by soldiers who had offered a sacrifice to them.

56) U. KNIGGE - A. RÜGLER, Die Ausgrabungen im Kerameikos 1986/87, in $A A 1989$, p. 81-99: Mention of a graffito on a lamp dedicated to Eros (p. 84, Athens, 4th c. BC).

57) D. KNOEPFLER, Le calendrier des Chalkidiens de Thrace. Essai de mise au point sur la liste et l'ordre des mois eubéens, in JS (1989), p. 2358 [ $B E$ 1990, 237.480]: K. studies the calendar of Euboia and Chalkidike in view of recent epigraphical finds [cf. $E B G R$ 1988, 68]. He supports the Euboean origin of the calendar in the Chalkidike and offers the following reconstruction of the names and sequence of months: Apatourion, Posideon (?), Lenaion, Anthesterion, Artemision, Olympion, Thargelion, Hippion, Pantheon (?), Heraion, Bouphonion, Demeterion (?).

58) L. KOCSIS, Inschriften aus dem Mithras-Heiligtum des Hauses des Tribunus Laticlavus im Legionslager von Aquincum aus dem 2.-3. Jh., in AArchHung, 41 (1989), p. 81-92: Ed. pr. of inscriptions found in the Mithraeum in the house of a tribune (Aquincum); among them a dedication to Asklepios in Greek (3), which originally stood in a valetudinarium and was later used in the Mithraeum. The other texts are dedications to Mithras Sol Invictus (1.2.4-8).

59) D. KOMATA, Nje mbishkrim votiv nga Dushkaraku (RR. I. Vlores), in Iliria, 19 (1989), p. 267-268 [BE 1990, 439]: Ed. pr. of a dedication to Poseidon and Amphitrite (Dushkarak, hell.).

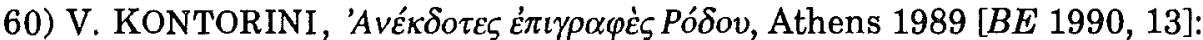
A collection of inedita from Lindos (1) and Rhodos (2-84). Lindos: An important decree concerning the purification of suppliants presents some analogies to the lex sacra from Kyrene ( $S E G$ IX 72), which can be explained in view of the Rhodian influence on Kyrene [cf. $E B G R$ 1987, 57]. The preserved fragment concerns the punishment of priests and heralds for acts contrary to the decree. The term

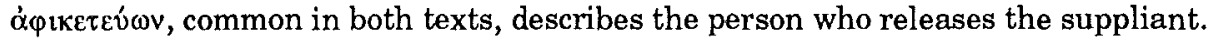
The decree probably stated that the money a priest could demand from the suppliant should not exceed a limit; a herald (cf. the $\pi \rho \circ \alpha \gamma \gamma \varepsilon \lambda \tau \eta \dot{\rho}$ in Kyrene) preceded the procession which the suppliant attended and warned the passers-by. The Lindian text probably distinguished the same three categories of suppliants as did the lex sacra of Kyrene. In view of the new find $\mathrm{K}$. suggests that the Kyrenaean lex sacra did not consider spirits or demons (as suggested by W. BURKERT), but human suppliants. Rhodos: Dedications to the gods (2.5, hell.), Apollon Stratagios (8, imp.), Helios and the Demos (6, hell.); the documents of a new cult association (eranos) of the Samothrakiastai Aristobouliastai (<Artemis Aristoboule) Hermaistai Panathenaistai (10 A-C, $2 \mathrm{~d} \mathrm{c}$. BC) include a list of donors, who contributed to the acquisition of land for the association's cemetery. New texts naming priests of Helios (53-62, 3d c. BC-3d c. AD) permit the localisation of Helios' sanctuary, which was probably a temenos without a temple. Apart from some dedications to the gods 
(63.66.70.73.74.77) and an altar for Poseidon, Demeter, the Dioskouroi, and Rhodos (71, hell.), the inscriptions found here name winners at the local games Rhomaia (62), Poseidonia (73), Halieia (73.74), Alexandreia (73), Dionysia (73), and Dioskuria (75). Note the honorary inscription for Eupolemos $(73,1$ st c. BC) who occupied, among other offices, those of a prophetes, priest of Athena Lindia and Zeus Polieus, and priest of Artemis Kekoia; $\mathrm{n}^{\circ} 62$ mentions an agonothetes of the Rhomaia.

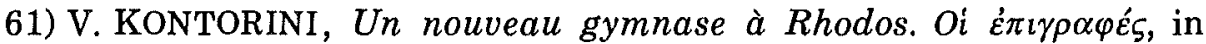
$A C, 58$ (1989), p. 157-177 [BE 1990, 262]: Ed. pr. of a dedication to Hermes by the epistates ton paidon, found in a gymnasion of Rhodos (hell.) and reedition of a dedication to the gods [ASAA, 2 (1916), $\left.\mathrm{n}^{\circ} 22\right]$.

62) Ch. KOUKOULI-CHRYSANTHAKI, in $A D, 38$ B2 (1983) [1989], p. 322: Report about the excavation of a sanctuary of the Thracian rider god (Kipia, Thrace). In two dediations he is called $\ddot{\eta} \rho \omega \varsigma$ Avi $\lambda \omega v \varepsilon i \tau \eta \varsigma$.

63) P. KRENTZ, Athena Itonia and the Battle of Koroneia, in H. BEISTER - J. BUCKLER (eds.), Boiotika. Vorträge vom 5. Internationalen Böotien-Kolloquium zu Ehren von Prof. Dr. S. Lauffer (1986), München 1989, p. 313-317: Ed. of two stamped Lakonian tiles, which probably name Athena. This find strengthens the assumption that the sanctuary of Athena Itonia is to be located north of Koroneia.

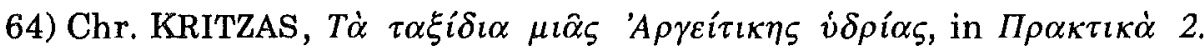

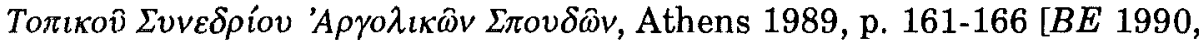
424]: An inscription on an hydria found in Sinope records that this vase had been given as prize at the Argive Heraia (ca. $460 \mathrm{BC}$ ). K. restores a second inscription, which shows that the same vase had been reused as a prize at the games in honour of the Dioskouroi in Pheneos, attested for the first time here. This prize was brought by the winner of these games to Sinope and was used later as his urn.

65) M.L. LAZZARINI, Iscrizioni dal santuario di Artemide (1984-87), in Syria, 66 (1989), p. 41-49: Ed. pr. of eight dedicatory inscriptions from the sanctuary of Artemis in Gerasa (imp.); the dedicated objects are honorific statues (1-6) and a bronze object (7); $n^{\circ} 8$ was dedicated by a priest for the salvation of the emperor.

66) B. LE GOUEN-POLlet, Sébastopolis du Pont (Sulusaray). Documents littéraires et inscriptions déjà publiées de la cité, in EA, 13 (1989), p. 51-86 [BE 1990, 28]: Collection of the published inscriptions of Sebastopolis. Dedications to: Zeus Pylaios (1), Pylon Epekoos (2), Theos Asklepios Soter (3), and the emperors Hadrian (4.5), Antoninus Pius (6), and Marcus Aurelius (7). Officials: high priests for the emperor cult (10.14), a thiasarches (10).

67) A. LÓPEZ JIMENO - J.M. NIETO IBAÑEZ, Nueva lectura de una defixio de Selinunte, in Emerita, 57 (1989), p. 325-327: New readings of a

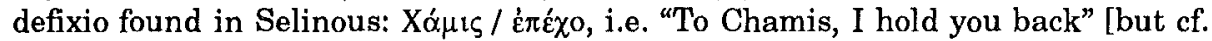
supra (29)]. 
68) A. ŁUKASZEWICZ, An Osiris "cool water" inscription from Alexandria, in ZPE, 77 (1989), p. 195-196 [BE 1990, 816]: Ed. pr. of a funerary inscription with the Osiris "cool water" formula which is attested in 12 inscriptions (Egypt, 2d/3d c.).

69) W. LUPPE, $Z u$ den neuen Goldblättchen aus Thessalien, in $Z P E, 76$ (1989), p. 13-14 [SEG 37, 497]: L. restores the last verse of the inscription on two Orphic gold leaves found in Thessaly [cf. $E B G R$ 1987, 112; supra (42), infra (71)]:

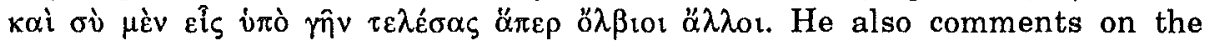
comparison of Dionysos with a ram (cf. P.Oxy. 663).

70) G. MANGANARO, Case e terra a Kamarina e Morgantina nel III-II sec. a.C., in PP, 44 (1989), p. 189-216 [BE 1990, 859.861]: Study of the lead tablets of Kamarina ( $3 \mathrm{~d} / 2 \mathrm{~d} \mathrm{c}$.) recording the sale of land and houses. Note the month names Geloios (I), Heraios (III), and Dionysios (VI), and a street named after Persephone ( $\Phi_{\varepsilon \rho \sigma \sigma o ́} \varphi \alpha \sigma \alpha$, II) and Herakles (VII). The analogous tablets of Morgantina mention an eponymous hieropolos (I. III) and the month names Apellaios (III), and Theodaisios (I, probably introduced from Kos).

71) R. MERKELBACH, Zwei neue orphisch-dionysische Totenpässe, in $Z P E, 76$ (1989), p. 15-16 [SEG 37, 497]: M. suggests some new readings in the

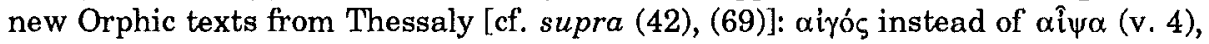

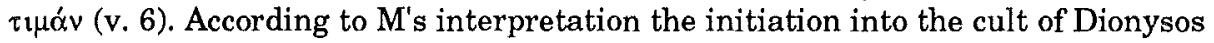
relieved the dead person from the sin caused by the death of Zagreus.

72) E. MIRANDA, Osservazioni sul culto di Euploia, in MGR, 14 (1989),

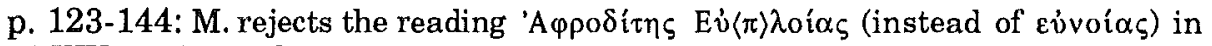
IG XIV 745 (Neapolis, 1st c. BC) and suggests that Euploea, mentioned by STATIUS, silv. II 2,79 in connection with Neapolis, is a place name and not a sanctuary of Euploia. M. also discusses the diffusion of the cult of Aphrodite Euploia and Isis Euploia (identified with Arsinoe II) in the hellenistic period.

73) K. MOCHIZUKI, Preliminary Report. Seventh Season of the Excavations at the Site of Akoris, Egypt 1987, Kyoto 1988 [SEG 38, 16781679, non vidi]: Ed. pr. of a dedication to Hera Aphrodite = Hathor and a fragmentary inscription probably with the invocation ['A $\alpha \alpha \theta \hat{\eta} 1]$ Tó $\chi \eta ı$ (Akoris, imp.).

74) J.-C. MORETTI, Travaux de l'École française en Grèce en 1988. Argos. 4. Le théâtre, in $B C H, 113$ (1989), p. 717-722: Mention of a graffito on an Attic vase naming Herakles (Argos, 5th c. BC).

75) L. MORETTI, Analecta epigraphica, in RPAA, 40 (1987/88) [1989], p. 236-251: $\mathrm{N}^{\circ}$ 6: Restoration of a metric dedication of a statue of Isis (called $\sigma \varepsilon \mu v \eta ́$ ) found in Chersonesos (SEG 35, 597) [SEG 38, 748]. $\mathrm{N}^{\circ} 8$ : Restoration of a dedication to Augustus and Tiberius (PAAH 1969, p. 104) mentioning a priest of

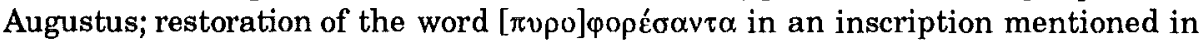
$P A A H$ 1971, p. 163-164 (Messene) [SEG 38, 342; cf. infra (86)].

76) L. MORETTI, La dedica dei Damasceni nell'area sacra di Largo Argentina, in $M G R, 14$ (1989), p. 205-213: Reedition of an honorific inscription for M. Licinius Crassus Frugi (AD 5/6) dedicated by the sacred and 
inviolable city of Damaskos. [Cf, now the restoration of G. ALFöLDY, Zwei augusteische Monumente in der Area Sacra des Largo Argentina in Rom, in Epigrafia: Actes du Colloque Int. d'épigraphie latine en mémoire de A. Degrassi, Rome 1988, Rome 1991, p. 667-690: A. recognizes as second dedicant of the

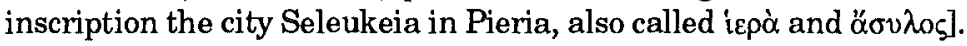

77) H. MÜLLER, Ein neues hellenistisches Weihepigramm aus Pergamon, in Chiron, 19 (1989), p. 499-553 [BE 1990, 147; SEG 37, 1020]: Ed. pr. of a metrical dedication to Dionysos and Attalos I (Pergamon, 3d/2d c.). Dionysiodoros of Sikyon, admiral of Attalos, dedicated a statue of the satyr Skirtos

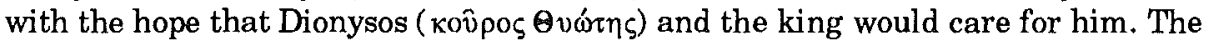
statue was inspired by the plays of Pratinas. M. comments on the cult of Dionysos Kathegemon in Pergamon and his role as god of the mysteries, theater, and art.

78) B.I. NADEL, Notes on the Kaisareion inscription from Taman, in M. PIÉRART - O. CURTY (eds.), Historia Testis. Mélanges d'épigraphie, d'histoire ancienne et de philologie offerts à Tadeusz Zawadzki, Fribourg 1989, p. 119-131: Discussion of a fragmentary inscription from Hermonassa on the Black Sea $(C I R B 1050, \mathrm{~m}$. 2d c. AD). N. argues that the inscription was not set up by a Bosporan king, but by a private person, who had established a Kaisareion and served as priest of the emperor cult. According to N.'s restorations the priest, responsible for the festival on the birthday of he emperor, should be elected among the members of the family of the founder. [Many restorations are very conjectural].

79) I. NICOLAOU, Inscriptiones Cypriae alphabeticae XXVIII, 1988, in $R D A C, 1989$, p. 141-150 [BE 1990, 809]: Ed. pr. of two dedications to Theos

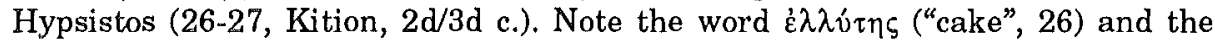
office of thyepolos (27).

80) 1. OPELT - E. KIRSTEN, Eine Urkunde der Gründung von Arsinoe in Kilikien, in ZPE, 77 (1989), p. 55-66 [BE 1990, 304]: Ed. pr. of an inscription containing a letter of Thraseas, governor of Kilikia, to Arsinoe and a decree of Nagidos. The Nagideis permitted the inhabitans of Arsinoe to establish a city-constitution and to keep the land given to them by Aetos, former governor of Kilikia and founder of Arsinoe [cf. supra (52)]. The decree of Nagidos attests the cults of Homonoia, Ptolemaios II, Arsinoe II, and Berenike in Nagidos and that of the Theoi Adelphoi (Ptolemaios II and Arsinoe II) in Arsinoe. [O.-K. supposed (p.63) that this decree of Nagidos established for the first time the cult of Homonoia, in order to record the friendship between the two cities; however the text implies that this cult already existed in Nagidos; cf. supra (52)]. Each city should contribute to the sacrifices of the other. The document was to be published in the sanctuary of Aphrodite in Nagidos and that of Arsinoe II in Arsinoe.

81) G. PACI, Per la storia del dominio Tolemaico in Cirenaica. Nuovo basamento in onore dei dinasti Alessandrini dall'Agorà di Cirene, in Egitto e storia antica, p. 583-593: Ed. pr. of an honorary inscription for Ptolemaios IX and Kleopatra, honoured as Theoi Soteres (Kyrene). 
82) O. PALAGIA - D. LEWIS, The ephebes of the Erechtheis, 332 / 2 B.C., and their dedication, in $A B S A, 84$ (1989), p. 333-344 [BE 1990, 138]: Discussion of the ephebic dedication SEG 29, 162 (Rhamnous, 333/2). P.-L. argue that the ephebes dedicated a statue of Nemesis and Themis after their victory at a torch-race in the Nemesia.

83) L. PALAIOKRASSA, Neue Befunde aus dem Heiligtum der Artemis Munichia, in $M D A I(A), 104$ (1989), p. 1-40: Report on the new excavations at the sanctuary of Artemis Mounichia in Piraeus and ed. pr. of a very fragmentary decree concerning this sanctuary (p. 19, late 5th c. BC).

84) E. PAPAKONSTANTINOU, in $A D, 37 \mathrm{~B} 1$ (1982) [1989], p. 136: Mention of a dedication made by an agonothetes at the sanctuary of Artemis Limnatis near Messene (imp.).

85) C.C. PETOLESCU, Cronica epigrafica a Romaniei (VIII, 1988), in Studii şi cercetari istorie veche si arheologie, 40 (1989), p. 389-399: Review of recent epigraphic publications in Rumania. Note a dedication to "H the Tracian rider god (509, Oituz, Moesia Inferior).

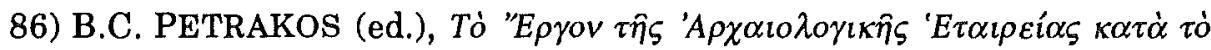
1988, Athens 1989: The annual report of the activities of the Arch. Society mentions numerous new inscriptions. Epidauros (p. 21): Dedication of an altar in the sanctuary of Apollon Maleatas in Epidauros (AD 111) by the pyrphoros of the

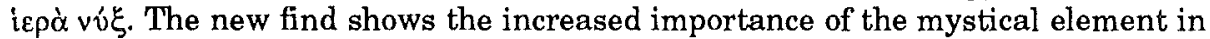
imperial times [ $B E$ 1990, 226]. Messene: A hell. dedication to Acheloos was found in a fountain, which can be identified as the fountain Klepshydra mentioned by PAUS., 4, 33, 1 (p. 28-29) [ $B E$ 1990, 176]. A decree found in the Sebasteion mentions a festival and athletic games on the birthday of Tiberius (p. 33). The new finds also

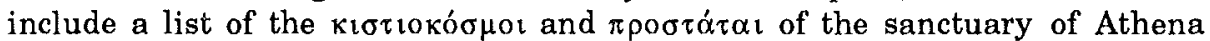
Kyparissia (hell. p. 37), two inscriptions mentioning a priest, an agonothetes (p. 37), and a priest of Artemis Limnatis (p. 45), a dedication to Zeus Kouthos found in the stadium (p. 42, imp.) and a dedication to Artemis (p. 46).

87) G. PETZL, Epigraphische Nachlese, in EA, 13 (1989), p. 127-133: Nº 3 a $=$ infra $(91) \mathrm{n}^{\circ} 109$.

88) G. PIANU, Scavi al santuario di Demetra a Policoro, in M. TORELLI (ed.), Studi su Siris-Eraclea, Roma 1989, p. 95-112 [BE 1990, 190; SEG 38, 993]: $P$. reports the find of a louterion dedicated to Demeter in her sanctuary (Herakleia, hell.).

89) F. PIEJKO, Two Attalid letters on the asylia and ateleia of Apollo Tarsenus, 185 B.C., in Historia, 38 (1989), p. 395-409 [SEG 37, 869]: Reedition (with many new readings) of two letters concerning the asylia of the sanctuary of Apollon Tarsenos (Welles 47). P. attributes both letters to Attalos I and dates them in the period after the peace of Apameia; they belong to a series of documents demonstrating the concern of the Attalid administration toward the affairs of former Seleucid dominions. The first letter orders the remission of a sales tax on sheep (probably sacrificial animals). 
90) Ch. PITERos, in $A D, 37$ B1 (1982) [1989], p. 172-173: Mention of dedications to Hygeia (Schimatari, Boiotia, 4th c. B), the Dioskouroi (= IG XIV 1726, Kreusis, imp.), and Herakles Leuktriades (Leuktra, imp.).

91) F.B. POLJAKOV, Die Inschriften von Tralles and Nysa. I. Die Inschriften von Tralleis (IGSK, 36,1), Bonn 1989 [BE 1990, 22]: Corpus of the inscriptions from Tralleis (no new texts and often no commentaries). Oracles: The oracle of Apollon Pythios concerning the establishment of the cult of Poseidon $(1,2 \mathrm{~d} / 3 \mathrm{~d}$ c. $\mathrm{AD}=\mathrm{H}$. W. PARKe -D.E.W. WormelL, The Delphic Oracle II, Oxford $1956,191 \mathrm{n}^{\circ} 471$ ), an oracle concerning the defence of Tralleis, probably reinscribed during the reign of Andronikos II Palaiologos (1282-1328, ${ }^{\circ} 2$ ). Leges sacrae: A lex sacra about the inviolability of the sanctuary of Dionysos $(3=L S A M$ 75,4 th c. BC; the text was reinscribed in the 1st c. AD), and a letter of Attalos III concerning the freedom of taxes given to Hiera Kome (18), a funerary foundation (220, imp., distribution of money? on the birthday of the dead donor), and a fragmentary text concerning sacrifices (254) [a hell. lex sacra; only the word $\chi 0$ îpos $\theta \hat{\eta} \lambda$ v can be recognized]. Dedications to: Apollon (9, cf. 17), Asklepios Soter (10), Pan (by a healed woman, 15), Theos Hypsistos (14), Zeus (4: two statues of eagles, hell.; 5: a statue of Dionysos), Zeus Larasios Eumenes (8, perhaps identified with Hadrian; his sanctuary is mentioned in $n^{\circ} 25.26 .28 .30$ ), Augustus and his Tyche (35), Agrippina Augusta (36); some dedications were made after dreams (14.15) and oracles (6); note two dedications of Hermes statues by priests of Hekate (1112). Officials: Asiarchs (69.73.85), high priests of the emperor cult in the province Asia (51.126-129.131) and in the city (88?.126-131.135.137-141), high priestesses (71.88), a high priest of the techniton synodos (65), priests and priestesses of unknown dieties (6.34.55.250 1. 10), priests of Hekate (12), Tiberius and Hekate Sebaste (Livia?, 11), Helios (134), Isis and Sarapis (86), the Roman Senate (16), Zeus Larasios (51.82.141.142), a priestess of Agrippina Augusta (36), an agonothetes of the local Pythia (82), a hieromnemon (25), stephanephoroi (26.69.80.88.134.145.256), an administrator of the revenues of Dionysos (13), $\pi \alpha \lambda \lambda \alpha \kappa^{\prime} \delta \varepsilon \varsigma$ (6.7), $\dot{\alpha} v v \pi \tau$ ró ${ }_{0} \delta \varepsilon \varsigma$ (6), and $\dot{\alpha} \mu \varphi \imath \theta \alpha \lambda \varepsilon \hat{\imath} \varsigma$ for the festival of Zeus (143); note that the temple prostitution was transmitted to the members of the same

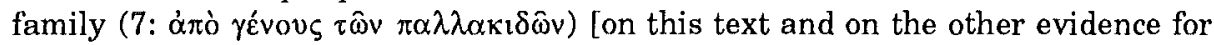
temple prostitution see now W. FAUTH, in $J b A C, 31$ (1988), p. 24-39]; the priests of Zeus Larasios served $\delta$ ì $\beta$ íov (51.82.141.142); many priests belonged to the same distinguished families (51.88); $n^{\circ} 87$ mentions a priestess of Artemis in Ephesos; the dedicant in $n^{\circ} 5$ was a temple slave. Festivals and games: a musical contest dedicated to Eumenes Soter (23) [the same festival is probably mentioned in $n^{\circ} 29$ 1. 14-15], Asklepieia (120), Dia (143), Haleia (142), Herakleia (141.144), Olympia

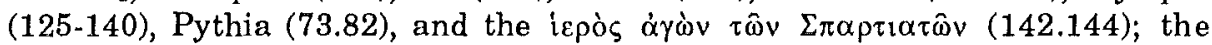
Koriasia in Kleitor are mentioned in $n^{\circ} 116$. Associations: of mystai (74.86.168) and hieronikai (105, 1st c. BC, cf. 109.112). $N^{\circ} 25$ mentions a sanctuary of Athena, $\mathrm{n}^{\circ} 250$ (1. 25) mentions a field called Priapion. The treaty of isopolity between Miletos and Tralleis mentions the theoria sent to the Didymaion and a sacrifice made for the success of the treaty $(20$, ca. 212/11). Numerous texts mention the titles of Tralleis as neokoros of the emperor cult (52.58.59.74.81.94) and the holy city of Zeus Larasios (74.81). N 21 concerns the asylia of the sanctuary of Artemis Leukophryene in Magnesia on the Maiander (3d c. BC). 
92) W.K. PRITCHETT, Studies in Ancient Greek Topography. Part VI, Berkeley-Los Angeles-London 1989 [BE 1990, 418]: P. discusses (p. 79-83) an inscription found on Mount Zavita prohibiting the damage of a KEveóptov and an

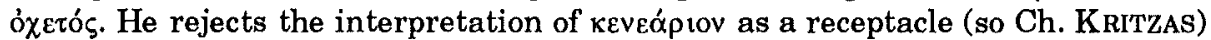

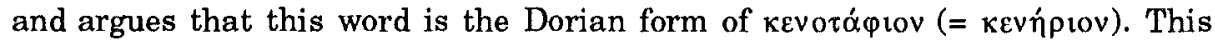
cenotaph had been erected after a battle between Spartans and Argives in the 5th $\mathrm{c}$. BC. [But see the objections of L. DuBOIS, in BE 1990, 418].

93) G. PUGLIESE CARRATELLI, Ripristino di famiglie Italiote, in $P P, 44$ (1989), p. 187-188 [BE 1990, 852]: P. reads the words $\dot{\alpha}$ yvvó and $\dot{\alpha} \gamma \varepsilon v \varepsilon \alpha \dot{\alpha}$ (instead of the personals names ATYNA, AГENEA) in two dedications to Hermes (Metapontion) $[E B G R$ 1988, 102] and Athena (Taras; Culti e miti della Magna Grecia, Firenze 1963, p. 37).

94) G. PUGLIESE CARRATELli, Dedica Metapontina a Afrodite, in PP, 44 (1989), p. 471-472 [SEG 38, 997]: Ed. pr. of a dedication to Aphrodite Meilichia (4th/3d c., Metapontion). This epitheton is also attested in Epidauros.

95) J.-P. REY-COQUAIS, Apport d'inscriptions inédites de Syrie et de Phénicie aux listes de divinites ou à la prosopographie de l'Égypte hellénistique ou romaine, in Egitto e storia antica, p. 609-619: Review of the diffusion of Egyptian cults in Syria and Phoinike in hellenistic and imperial times. It includs the discussion and edition of two important inscriptions: a) Ed. pr.

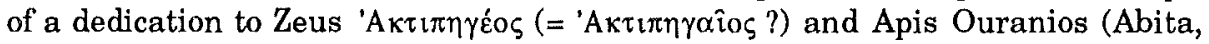
Syria, AD 321); the dedicant had restored water sources, which were believed to heal children and give fertility to women. The epitheton of Zeus is unique; it probably derives from the word $\pi \eta \gamma \eta$ (water source). b) Reedition with corrections of a dedication to Kronos Kyrios, after an oracle of Zeus and Apis of Abita (AD 166). The inscription mentions a priest $\delta i \alpha$ aiov as the eponymous official of the city, whose main cult was that of Zeus and Apis. The cult of Apis is attested in Syria and Phoinike only in Abita. R.-C. also mentions an unpublished dedication to Sarapis and his synnaoi (Tyros, $3 \mathrm{~d}$ c. $\mathrm{BC}$ ).

96) K.J. RIGSBY, Two inscriptions from Mysia, in Hermes, 117 (1989), p. 246-250 [BE 1990, 264]: Discussion of the dating formulas in the sumptuary law of Gambreion concerning funerals (hell.; LSAM 16). The lex sacra is dated by the hieronomos Demetrios, i.e. the official under whose jurisdiction this matter fell. The obligation to inscribe the law is dated by the stephanephoros Demetrios, i.e. the eponymous official of the city. It is not certain if the two Demetrioi were one person, i.e. a stephanephoros who also served as hieronomos.

97) T. RITTI, Oracoli alfabetici a Hierapolis di Frigia, in MGR, 14 (1989), p. 245-286: Reedition and discussion of a series of related alphabetical oracles from Tymbriada [EBGR 1988, 23], Hierapolis, and Soloi. The dieties mentioned in the oracles of this series differ from place to place; e.g., the oracles from Hierapolis name the local god Apollon Kareios in a verse, while the other oracles name Sarapis. After a detailed study of the analogies in the expressions found in the alphabetical and the astragalous oracles, $R$. rejects the view that the alphabetical oracles derived from the astragalomanteia. She also doubts if the two oracles found in Hierapolis were really used for divination. 
98) L. - J. ROBERT, Claros I. Décrets hellénistiques. Fascicule I, Paris 1989 [BE 1990, 17]: Ed. pr. with thorough commentary of two long honorific decrees of Kolophon for Ptolemaios (1) and Menippos (2) (Klaros, late 2d c. BC). The decrees describe in detail the career and achievements of the honoured persons. Ptolemaios had sacrificed to the gods after his victories in iєpoi $\dot{\alpha} \gamma \hat{\omega} v \varepsilon \varsigma$ (I 6-7, p. 21). He was sent as theoros to Smyrna (I 28-36, p. 26), probably for the festival of Nemesis [this in not certain; in 1. 30-32 it is said that he offered $\tau \dot{\alpha} \varsigma$

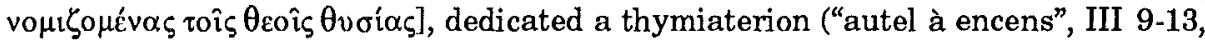
p. 40-41), and served as priest (of Apollon Klarios?, III 15, p. 42) and agonothetes of the Klaria (IV 35-53, p. 51). He also demonstrated his gegenorisity during his wedding (IV 24-34, p. 49-50) by offering a sacrifice for the common salvation; he distributed the meat of the sacrificed animals and gave permission to take it away

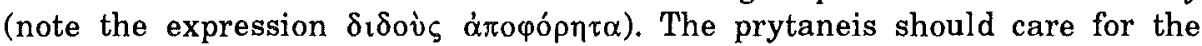
announcement of these honours during the Dionysia; the agonothetai were responsible for the announcement during the Klaria and all other games. His statue was to be erected in the sanctuary of Apollon Klarios near the altar of the Charites, propably as an expression of the sentiments of gratitude ( $\chi \alpha$ ó had offered thanksgiving sacrifices after the liberation of some captivated Kolophonians (I 49); he was in the same year agonothetes of the Klaria and

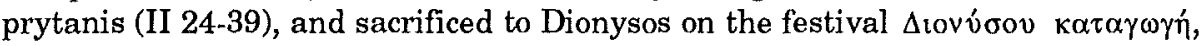
i.e. the festival of the arrival of Dionysos (p. 95-98). This is the first epigraphic attestation of the festival. Menippos received the same honours as Ptolemaios.

99) I.I. RUSSU, Inscriptiones Daciae Romanae. Volumen III. Dacia Superior. 4. Pars Orientalis, Bucarest 1988: This corpus of Dacian inscriptions includes Latin texts, which pertain to the cults of various dieties common to both Greeks and Romans (Adrastia: 215; Aesculapius: 233; Apollo: 207; Diana: 45.46.56.66.67.271-274; Hygia: 233; Juppiter Dolichenus: 86); note a bilingual dedication to Diana (46: $\Delta \mathrm{i} \alpha \dot{v} \eta$ ).

100) T. SARIKAKIS, Inscriptions inédites de Chios, in $B C H, 113$ (1989), p. 347-350: Ed. pr. of a vow of a man on behalf of his brother and for the salvation of his own son (2, Chios, imp.). Following an oracle given to him the dedicant promises to offer a sacrifice ( $\sigma \omega r \eta \dot{p}(\alpha)$ and dedicate a statue, if the god should heal

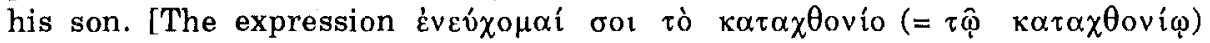
$[\sigma] v \sigma \sigma \hat{\omega} \sigma \alpha_{l} \mu \sigma[1] \tau \dot{0} \pi \alpha_{l} \delta$ iov shows that the vow was also addressed to an underworld daemon]. $\mathrm{N}^{\circ} 5$ is an unedited dedication to Herakles and the Demos by the winners of athletic games (Chios, 1st c. BC).

101) M. SAYAR - P. SIEWERT - H. TAEUBER, Inschriften aus Hierapolis-Kastabala. Bericht über eine Reise nach Ost-Kilikien (mit einem Beitrag von J. RUSSEL), Wien 1989: Ed. pr. of inscriptions from Hierapolis (imp.): A dedication to Faustina Nea Hera (1), altars dedicated to Asklepios and Hygeia Theoi Soteres (5), Helios Soter (6), and various emperors (819). $\mathrm{N}^{\circ} 7$ is an altar dedicated to Theos Pyretos (Dea Febris); this is the first

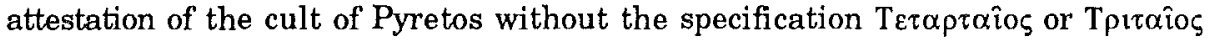
(Febris Quartana or Tertiana). 
102) P. SCARPI, La deificazione del defunto nelle lamine auree dell'antica Thurii, in MusPat, 5 (1987), p. 197-217: General discussion of the deification of the dead expressed in the Orphic leaves from the region of Thourioi (group A).

103) P.J. SIJPESTEIJN, Remarks on some magical gems, in Aegyptus, 69 (1989), p. 119-121: S. offers some new readings in magical gems published by M. MAASKANT - K. LeIBRINK, Description of the Collections in the Rijksmuseum G.M. Kam at Nijmegen. X. The Engraved Gems, Roman and Non Roman,

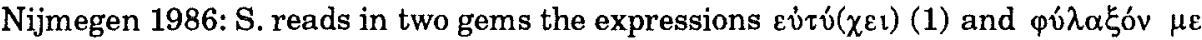
(2). In a gem (3) he recognizes the symbol of a uterus and the magical word OP $\Omega$ PIOY $\Theta$, which is often found on intaglios with the representation of a uterus closed by a "key".

104) M. SILVESTRINI, Cibele e la dea Siria in due iscrizioni di Egnazia e Brindisi, in Epigraphica, 51 (1989), p. 67-84: Ed. pr. of a Latin dedication made ex imperio (after a command of the goddess); the text mentions a priest of Mater Magna and Syria Dea (Egnatia, 1st c. AD). S. also discusses the epitaph of a priest of Meter Magna and Syria Dea who is called sacer Isidis (Brundisium, 1st/2d c.; CIL IX 6099); the last expression does not mean that the deceased was a priest of Isis, but only a devotee to her cult. S. makes general remarks on the associations for the cult of Kybele (Meter) and Dea Syria/Aphrodite Syria/Atargatis in Central Italy.

105) R.R. SIMMS, Isis in classical Athens, in CJ, 84 (1988/89), p. 216-221: S. discusses the Athenian decree proposed 333/32 by Lykourgos, which permitted the merchants from Kition to found a sanctuary of Aphrodite (IG $\mathrm{II}^{2} 337$ ). This cult should be established on the same terms as that of Isis. This text is the earliest testimony for the establishment of the Isis cult in Athens. S. argues that the same Lykourgos had also proposed the decree which allowed the Egyptians to found a sanctuary of Isis. Lykourgos was not interested in the cult of Isis itself, but aimed at attracting Egyptian merchants and vitalizing the Athenian economy (for an analogous plan cf. XEN., Poroi, 3, 1-2).

106) Sotheby's Sales Catalogue. Antiquities, London 23d May 1988, London 1988 [SEG 38, 1913, non vidi]: Mention and photo of a stele with a representation to Hermes, dedicated to Apollon (380, unknown origin, imp.).

107) Sotheby's Sales Catalogue. Antiquities and Islamic Art, New York 2nd December 1988, New York 1988 [SEG 38, 1914, non vidi]: Mention and photo of a dedication to Sozon (93, unknown provenance, imp.).

108) V.F. STOLBA, A new dedication from the North-Western Crimea and aspects of the cult of Herakles in the Chersonese State, in VDI (1989), p. 55-70: Ed. pr. of a graffito with a dedication to Herakles Soter (Panskoe, 4th c. $\mathrm{BC)}$; this is the first attestation of Herakles' cult in the area of Chersonesos. S. rejects the supposed chthonic character of Herakles' cult in this region and underlines its protecting aspects. 
109) A. TESSIER, La struttura metrica della laminetta di Hipponion. Rassegna di interpretazioni, in MusPat, 5 (1987), p. 232-241: Survey of the readings and restorations of the Orphic leaf from Hipponion, especially of the studies on its metrical structure.

110) P. THÉMELIS - D. MULLIEZ, Un acte d'affranchissement delphique inédit du trésor de Cnide, in $B C H, 113$ (1989), p. 343-346: Ed. pr. of an inscription recording the manumission of a slave through dedication to Apollon (Delphi, 2d/1st c.).

111) A. THÉ ODORIDES, Pèlerinage au Colosse de Memnon, in CE, 64 (1989), p. 267-282: T. offers a general discussion of the inscriptions, which record visits to the Colossus of Memnon in Abydos and sketches the philosophical and religious atmosphere, which gave rise to these pilgrimages. This phenomenon expresses the continuity of religious culture in Egypt from the Pharaonic to GrecoRoman times, especially in regard to the idea of the creator of the world, which is connected with the cult of Abydos. The popularity of Memnon lies in his role as a link between the humans and the gods.

112) G. THÜR, "Quittung" oder "Schuldschein"? Zu einem Bleitäfelchen aus Hyampolis, in ZRG, 106 (1989), p. 545-546: An inscription on metal found in the sanctuary of Kalapodi [EBGR 1987, 35] does not register the repayment to the sanctuary of the capital of a loan, but is a certificate of indebtedness. The city guaranteed that the sanctuary would receive the interest of $12 \%$.

113) G. THÜR, Review of L. DUBOIS, Recherches sur le dialecte arcadien, Louvain-La-Neuve 1986, in $Z R G, 106$ (1989), p. 604-605: $T$. offers a critical review of the recent interpretations of the "Gottesurteil von Mantineia" (IG V 2,262) by L. DUBoIS and A. LILlo [EBGR 1988, 99]. This inscription concerns the condemnation of murders by Athena Alea by means of an oracle. T. interprets the word $\gamma v \omega \sigma$ í $\alpha$ in 1.15 as a judicial decision (and not an

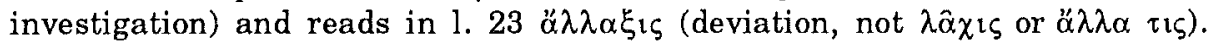
According to $\mathrm{T}$. the document considers two ways of condemnation of the accused persons, either by means of an oracle or through a law court ( $\eta$ rvorial $\kappa \alpha \tau \alpha \kappa \rho \imath \theta \hat{\eta} \imath)$.

114) G. THÜR - G. STUMPF, Sechs Todesurteile und zwei plattierte Hemidrachme aus Dyme, in Tyche, 4 (1989), p. 171-183: Discussion of Syll ${ }^{3}$ 530 (Dyme, early 2d c. BC) which records the condemnation to death of magistrates and cutters who had forged coins by using bronze instead of silver.

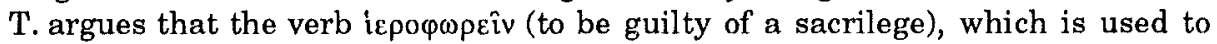
describe the offence of these persons, does not mean that they had stolen bronze or a stamp from a temple. He offers three alternative interpretations: a) Forgery of coins was regarded as a sacrilege, b) Dyme accused these persons of a sacrilege because there existed no law about forgery of coins; $c$ ) the condemned persons had embezzled money belonging to the deity.

115) Tituli Asiae Minoris. Vol. V. Tituli Lydiae linguis Graeca et Latina conscripti. Fasciculus II. Regio septentrionalis ad occidentem vergens. Schedis ab IOSEPHO KEIL elaboratis usus enarravit PETRUS HERRMANN, Wien 1989 [BE 1990, 19]: This valuable corpus includes the 
inscriptions from NW Lydia. New texts are marked with an asterisk. Most inscriptions are of imp. date. Attaleia: Dedications to: Asklepios (826), Soter (Asklepios?, *827). Cult officials: priests of Zeus $\pi \dot{\alpha} \tau \rho$ tos $\theta \varepsilon o ́ \varsigma$ (828, father and son), and priests for the city emperor cult (829). Also note a funerary imprecation (*853). Thyateira: $\mathrm{N}^{\circ} 860$ concerns the leasing of a sanctuary (probably dedicated to the emperor cult). $N^{\circ} 1055$ records the dedication of an altar for a dead priestess by the association of mystai; the deceased priestess was believed to have divinatory powers; people seeking the truth should pray ( $\varepsilon^{v} v \dot{v} \chi \varepsilon \sigma \theta \alpha \mathrm{l}$ ) in front of her altar, in order to receive an answer by means of visions ( $\dot{\alpha} \alpha \dot{\alpha} \mu \alpha \tau)$ ), either by day or night (imp.). Dedications to: Apollon Pityaenos (881, as thanksgiving for the salvation of the dedicant's son, who had been captured by the Galates), Apollon Tyrimnos and the Patris (882.883), Artemis Boreitene and the Patris (884), Asklepios Soter and Hygeia (885.886), Augustus (902), the Boule (925), Dea Roma, Augustus, and the Demos (903), Dea Iulia Augusta (904-906), Hadrian Zeus Olympios Soter Ktistes

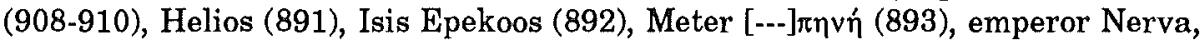
the Roman Senate and the Imperium Romanum ('P $\omega \mu \alpha i \omega v$ 'H $\gamma \varepsilon \mu o v i \alpha, 907$ ), Theoi Sebastoi (861-862), Theos Hypsistos (897-899), Theos Hypsistos and Epekoos

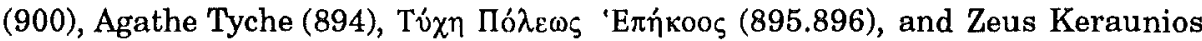
(889.890); the dedicated objects include statues of the Demos (887.888), altars (883.903), a $\lambda_{L} \beta \alpha v \omega \tau \rho i \varsigma(883)$, and statues of Herakles, Tyrimnos, Ganymedes, Dikte, and Bellerephontes in the local gymnasia (926); note a dedication $\kappa \alpha \tau$ ' $\dot{\varepsilon} \pi \imath \alpha \gamma \eta \dot{ } v$ (892); some dedications were made by the priests of the respective gods (883.902); the dedication to Iulia Augusta was made in fulfillment of the testament of a Iulia (904-906). Officials: high priests for the emperor cult in the city (934.950.951.954.966.969.976.979.980.1004.1020.1038?.1179) and the province (931.933.944.950.951.954.966-968.973.976.980; in Pergamon: 950; in Thyateira: 951), high priestesses of Asia (951.954) and of the city (951.954.957), a high priest of Augustus and Dea Roma (1098), Asiarchai (933.966.967.969), priests for the emperor cult (913.972), priests of Propator Theos Helios Pythios Apollon Tyrimnos/Tyrimnaios (883.913.935.984.1025, cf. 931; cf. 1001: priest $\pi \rho \grave{~} \tau \hat{\eta} \varsigma$ $\pi$ ó $\lambda \varepsilon \omega \varsigma$ ), Augustus (902), Dea Roma (903.940), and Dionysos Kathegemon (976.979), a priestess for the emperor cult (972), priestesses of Artemis (931.995.996.1002.1003), Tyche (951), Tyche Poleos (954), and Meter Theon (962.963.996), neokoroi of the Kaisareion (913.957; cf. 954), hymnodoi (955.962) and theologoi (962) for the cult of Meter Theon, agonothetai (857.928.929.931.943.944.946.948.956.960.961.966.969.976.978.980.983.990.992.993. 997.998.1000.1017.1020.1036.1176.1179) and agonothetides (904-906.931.963.972.

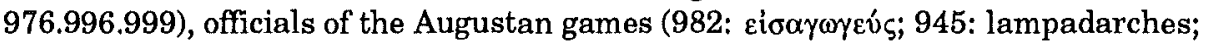
970: panegeriarchos), an athlothetes of the Asklepieia (1029), amphithaleis of various games (998; 1013: Asklepieia; 1024: Antoneia), a high priest of a xystos (984.1004), stephanephoroi (931.965.969.974.976.980.992.998.1023), a neokoros of

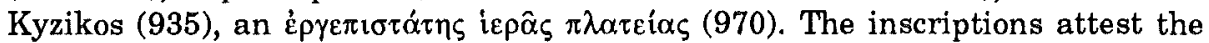
tenure of various offices by the same person (931: priest of Apollon, stephanephoros, and high priest of Asia; 933: high priest of Asia and Asiarches; 950.951: high priest of Asia and of Thyateira; 951.954: priestess of Tyche and high priestess of Asia twice; 966: Asiarches and high priest; 969: high priest and agonothetes; 979: high priest and priest of Dionysos Kathegemon; 996: priestess of Artemis and of Meter Theon), the tenure of cult offices by members of the same 


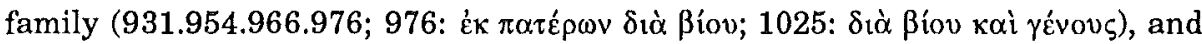
the tenure of many priestly offices $\delta ı \alpha$ oíov (934.950.966.980: high priest; 1025: priest of Apollon Tyrimnos; 976: priest of Dionysos Kathegemon; 984: high priest of a xystos; 972: high priestess; 951.954: priestess of Tyche Poleos; 963.996: priestess of Meter Theon; 968: agonothetes). Festivals and games: Megala Augusteia Isopythia Iselastika (945.970.980.1018.1019.1022, games and panegyris), games and panegyris for Theos Propator Helios Pythios Apollon Tyrimnos/Tyrimnaios (946.956.983.992.993.996.997?.1000.1001; cf. 998: Sebastoi Tyrimneioi agones; 1010-1011: Tyrimneia Megala; cf. 960: Sebasteios and Tyrimneios), games for Asklepios Soter (948.1021.1024; cf. 1013.1017: Megala Asklepieia), commemorative games for the victories of Severus Alexander (AD 233; 949.1007.1009: Sebereios agon; cf. 1008-1016: Epinikia), Megala Hadriana Olympia (1026), Antoneia (1024), Severeia (1007-1009), a panegyris for the Augusti and Apollon Tyrimnos (960.1001). Cult associations of: Herakleiastai (959), Iouliastai (1098 for the cult of

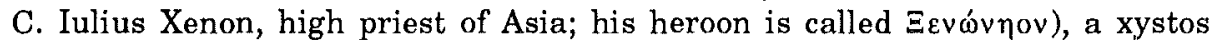

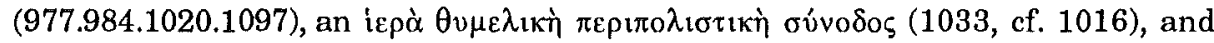
mystai (1055). A fragmentary letter by a Roman governor of Asia concerns

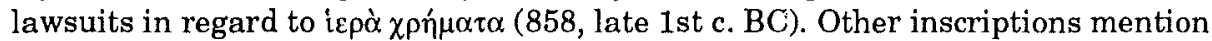
a monthly sacrifice, probably for a king $(855,2 \mathrm{~d} \mathrm{c.} \mathrm{BC),} \mathrm{the} \mathrm{sacrifices} \mathrm{for} \mathrm{and} \mathrm{the}$

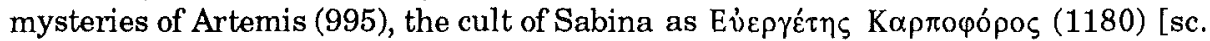
Demeter; cf. e.g. the cult of Sabina as Nea Demeter in Hadrianeia: EBGR 1987, 104 $\mathrm{n}^{\circ} 132$ ], a temple (857), the Hadrianeion (982), donations made during the festival

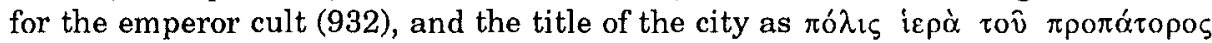

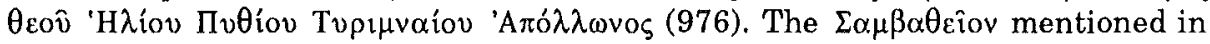
$\mathrm{n}^{\circ} 1142$ was probably a sanctuary of the Chaldaean Sibylla (or a synagogue). Note the dedication of altars for the cult of the dead (1048.1101.1127.1128. 1137.1139.1146), the characterization of a dead person as

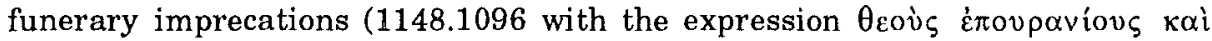

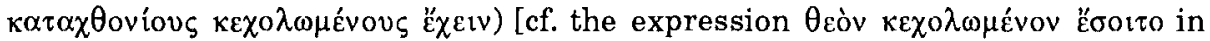
the Christian epitaph $n^{\circ} 1157$; on this expression see $\left.E B G R 1988,72\right]$, and epitaphs

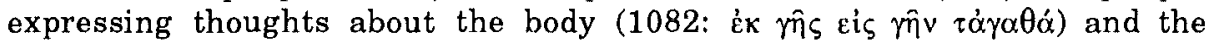
immortality the soul (1069.1108, imp.); $n^{\circ} 1069$ is another example for the

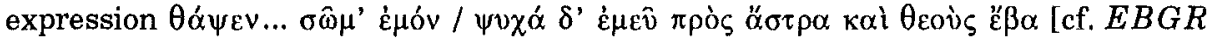
$1987,10 ; 1988,32.124 .179]$; in the epigram $n^{\circ} 1108$ (=GVI 1993) the deceased person appears to his mother and reports that his soul had been brought to heaven

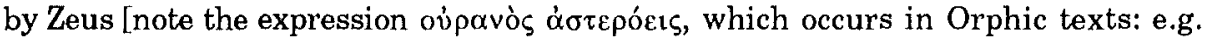

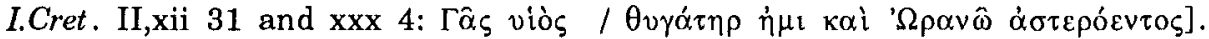
Apollonis: Dedications to: Apollon Pingeanos (1183), Artemis and the Polis (1184), Thea Euanthetos (1185), Zeus Misnyenos (1186): Officials; priests of Dea Roma

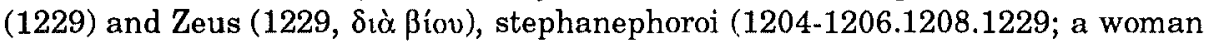
in $\mathrm{n}^{\circ}$ 1208), a panegyriarchos in Pergamon (1192), and agonothetai (1184-1198). Hermokapelia: An agonothetes is mentioned in $\mathrm{n}^{\circ}$ 1237. Hierokaisareia: Dedications to: Aphrodite (1255), Apollon Paian (1250), Asklepios (1254), Dionysos Erikepaios (1256), Thea Synkletos Epiphanes (1264, i.e. the Roman Senate), Theoi Sebastoi, Artemis Persike, and the Demos (1244, cf. 1245), Theos Hypsistos (1258), Zeus Ktesios (1257), and anonymous deities (1259.1260); note the dedication of

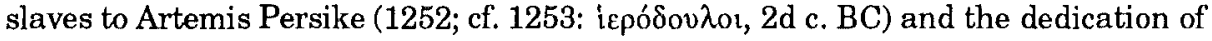
a garland by the winner of a wrestling contest (1277). Officials: hieronomoi 
(1246.1252.1253.1265. 1266.1268), a priest of Dionysos (1247), Roma (1250), agonothetai (1270-1276), an hierophantes of the Dionysos' cult (1256), and a stephanephoros (1267). The inscriptions also mention the games Artemisia (Megala Artemisia: 1271.1276; Sebasta Artemisia: 1272-1275; cf. 1265.1270), the boundary stone of a sanctuary of Artemis, which had the privilege of asylia (1251), and an association ( $\sigma v \gamma \gamma \varepsilon \dot{v} \varepsilon 1 \alpha$ ) for the cult of Dionysos. $N^{\circ} 1281$ (epitaph) orders that the fine for the violation of the grave should by payed for the sacrifices to the emperor. Hyrkanis: Dedications to: Ma Aniketos (1305, the only attestation of her cult in Lydia), Meter Theon and Zeus Seleukeos in fulfillment of a vow (1306,

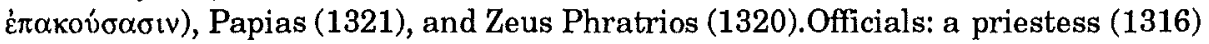
and stephanephoroi (1309.1317.1323). The sacrifices for Herakles and Aphrodite are mentioned in $n^{\circ} 1316$ (1st c. $B C$ ). $N^{\circ} 1335$ reports the construction of a temple of Demeter Karpophoros, dedicated to the emperors, the Senate, and the populus

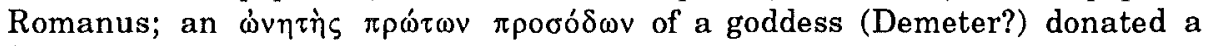

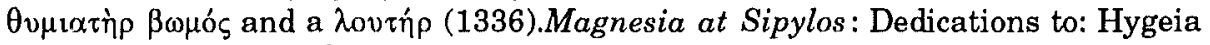

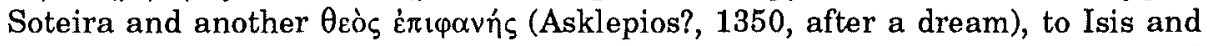
Sarapis (1348, 1st c. BC), Meter Theon Plastene (1353-1356), Meter Sipylene and the Demos (1357), a godess called Epekoos (Hekate?, 1347); note the dedication of a statue of Semele (1349) and the list of temple slaves $(\theta \varepsilon \rho \alpha \pi \varepsilon v \tau \alpha i)$ written on an older dedication to Isis and Sarapis (1348, 2d c. AD). Officials: priests of Isis (1348) and an anonymous deity (1367), stephanephoroi (1343.1345.1367.1368.1386). $N^{\circ} 1352-1356$ were found in the sanctuary of Meter Plastene ( $n^{\circ} 1352$ record the construction of her temple); a funerary imprecation (1371); $\mathrm{n}^{\circ} 1375$ provides for the payment of a fine to Meter Theon Sipylene for the violation of a grave. Inscriptions from the area to the north of Magnesia: the letter of a hellenistic king concerning the asylia of the sanctuary of Persike Thea (1396=OGIS 333); dedications to Theos Hypsistos (1400, an altar and $\left.\lambda v \chi v \alpha \psi \psi_{i} \alpha \mathrm{l}\right)$ and Zeus (1412); the honorific inscription for a prophet of Apollon Pandenos mentions a neokoros and a panegyris (1411); also note the office of stephanephoros (1401.1409).

Also note the cognomen Sakerdotianos (of a priest, 979, Thyateira), expressions

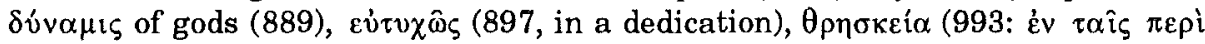

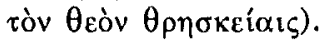

116) G. TOUCHAIS, Chronique des fouilles et découvertes archéologiques en Grèce en 1988, in $B C H, 113$ (1989), p. 581-700: T. mentions the discovery of a hell. dedication to Apollon Hekatombaios in the area of Ptolemais (p. 643); he also mentions the inscriptions reported supra (86) (Epidauros and Messene).

117) J. TRÉHEUX, Bulletin épigraphique. Attique, in $R E G, 102$ (1989), p. 415-421: T. makes some corrections to a temple inventory [SEG 34,95]; he rejects MERITT's view that the sanctuary was that of Dionysos Melpomenos, since a female deity (Aphrodite Hegemone or Aphrodite Ourania) is mentioned in 1. 29 (p. $418 \mathrm{n}^{\circ} 373$ ). T. also points out that the inventory $S E G 35,1731$ does not refer to a Delian sanctuary, but to Eleusis.

118) Y. TSAFRIR, Further evidence of the cult of Zeus Akraios at Beth Shean (Scythopolis), in IEJ, 39 (1989), p. 76-78 [=EBGR 1987, 111]: Ed. pr. of an altar dedicated to Zeus Akraios (Skythopolis, 2d c. AD), whose cult in Palestine is 
attested only in Skythopolis. The dedicant has a Greek name, whereas his father bears the Hebrew or Aramaic name Tobias.

119) A. TZIAPHALIAS, in $A D, 37$ B1 (1982) [1989], p. 238-240: Mention of new dedications to Apollon, Apollon Doreios, Apollon Pythios, Artemis, Artemis Eileithyia, Artemis Phosphoros, Hermes Chthonios, Poseidon, Poseidon Patroos, and Poseidon (Pythion of Elasson, hell.).

120) M. ÜNDEMIS - D.H. FRENCH, Two gladiatorial texts from Claudiopolis in Bithynia, in EA, 13 (1989), p. 91-97: Ed. pr. of a grave inscription (1) set up by a munerarius, priest of the emperor cult, for gladiatiors who had participated in the games during the celebration of the emperor cult.

121) H. VAN EFFENTERRE, De l'étéocrétois à la selle d'agneau, in $B C H$, 113 (1989), p. 447-449: A new hell. inscription from Eleutherna attests, for the first time, the word $i \pi \varepsilon p \mu \eta p i \delta i \alpha$ ("selle d'agneau") as a description of a part of a sacrificial animal. The same word is to be read in an archaic inscription from Dreros (M. BILE, Le dialecte crétois, Paris 1989, p. 31 n 7).

122) E. VARINLIOĞLU, Die Inschriften aus dem Museum von $U_{s a k}$, in $E A, 13$ (1989), p. 17-36: Ed. pr. of two funerary imprecations (4.6, imp.) and an epitaph expressing the belief on the immortality of the soul (13, imp., Lydia).

123) E. VARINLIOGLU, Eine Gruppe von Sühneinschriften aus dem Museum von $U_{\$} a k$, in $E A, 13$ (1989), p. 37-50: V. discusses the "confession inscription" of Theodoros (Lydia, imp.) [SEG 38, 1237; $E B G R$ 1988, 105 and 144]; he rejects the view expressed by G. PETzL $[E B G R$ 1988, 144] that Theodoros had been punished for his sins by being imprisoned for two years in the temple; the

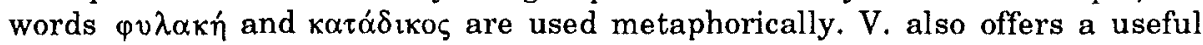
discussion of the procedure followed by the sinners and the priests: The sick persons went to the temple to ask the god for help; there they confessed their sins and performed rituals which freed them from sin and sickness alike. These rituals are described in two of the new confession inscriptions published here with thorough commentary (infra, $\mathrm{n}^{\circ} 4-5$ ). $\mathrm{N}^{\circ} 1$ : Confession dedicated to Mes Axiottenos

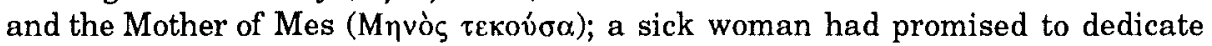
an inscription if she should be healed, but failed to fulfill her vow (AD 175/6). $\mathrm{N}^{\circ} 2$ :

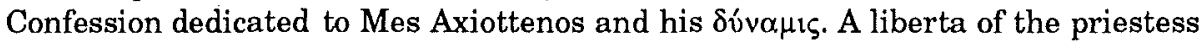
had made a vow for her sick son, "that if he should become healthy without wasting money on doctors, she would write it on a stone"; as she failed to fulfill the vow, "the god demanded it and punished the father Philemon" ( $2 \mathrm{~d} / 3 \mathrm{~d}$ c.). $\mathrm{N}^{\circ} 3$ : Confession of a woman who had been punished on her right breast by Mes Axiottenos for failing to repay the amount of corn she had borrowed from the temple ( $\mathrm{AD} 132 / 3) . \mathrm{N}^{\circ} 4$ : The confession begins with acclamations ( $\mu \varepsilon \gamma \alpha \dot{\alpha} \lambda \eta, \mu \varepsilon \dot{\gamma} \gamma \varsigma$ ) to Meter, the Mother of Mes, Mes Ouranios, Mes Artemidorou Axiottenos ('A $\xi_{10} \tau \tau \alpha$

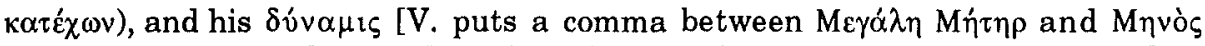

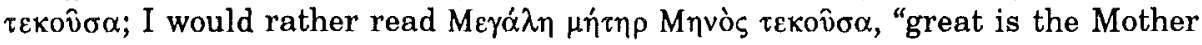
who gave birth to Mes"]. A six year old boy had been punished by god for wearing unclean clothes; the sin was taken away by means of a $\tau \rho \iota \varphi \omega v i o v(\hat{\eta} \rho \varepsilon \tau \rho i \varphi \omega ́ v i o v$, see $n^{\circ} 5$ ). $\mathrm{N}^{\circ}$ 5: Confession dedicated to Zeus Or(e)ites and Mes Axiottenos "the king

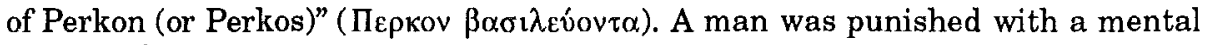
disease $(\theta v \mu \mathrm{o} \lambda v \sigma i \alpha)$ because he had crossed the boundary of a sanctuary by 
mistake. "As soon as the inscribed stele was erected, he took away ( $\dot{\alpha} \pi \hat{\eta} \rho \varepsilon v$ ) the

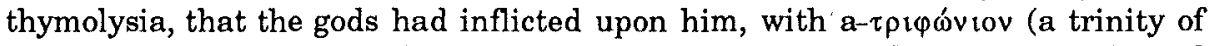
animals, a trinity of voices), with a mole and a sparrow and a tuna; a modios of wheat, one prochus of wine, breakfast for the priests, 1,5 kypros of wheat, 1,5 prochus of wine, chick-peas and wheat groats". After this ritual the sinner expiated the gods for the sons of his sons and the grandchildren of his grandchildren. V. rightly points out the analogy of the procedure described here with old oriental rituals: The sin together with the sickness is transferred to three animals, which are then released to take the evil away. [It is interesting to note that the trinity of animals represents the three basic elements of the world, the earth (mole), the air (sparrow), and the water (tuna). An analogous symbolical character of the animals used in these rituals can be recognized in the confession of Theodoros ( $E B G R$ 1988, 105 and 144): The first sin had been removed with the help of three animals representing three different elements, the earth (sheep), the sky (partridge), and the underworld (mole); whereas in the case of the third sin we have to do with a trinity of animals of the same kind, i.e. three birds (chicken, sparrow, pigeon); in the

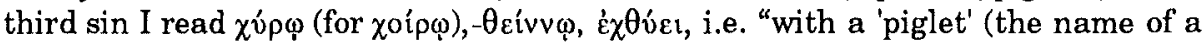
fish, see LIDDELL-SCOTT), a tuna, and (another) fish"; on the contrary, if we follow

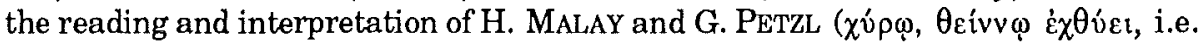
"mit einem Ferkel und einem Thunfisch"), there is no triphonion]. The new texts give further examples of the terms often attested in propitiatory inscriptions:

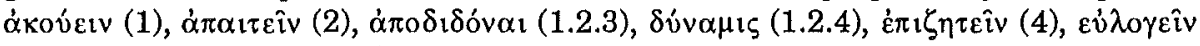

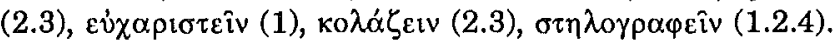

124) I. VOKOTOPOULOU, in $A D, 37$ B1 (1982) [1989], p. 286: Mention of an epitaph with the theophoric name Artemis.

125) M.B. WALBANK, Greek inscriptions from the Athenian Agora, in Hesperia, 58 (1989), p. 71-97: Ed. pr. of a prytanee decree (25, Athens, ca. 250 $\mathrm{BC})$ with the banal formula that the prytaneis had fulfilled their religious obligations (sacrifice to Apollon Prostaterios before the assembly).

126) C.K. WILLIAMS - O.H. ZERVOS, Corinth, 1988: East of the theater, in Hesperia, 58 (1989), p. 1-50: Further frescoes were revealed in the private house where the graffito naming Anteros was found (Korinth, early 3d c. AD) [EBGR 1988, 192]; the representation of Eros (among other dieties such as Herakles, Zeus, Hera, Athena, and Artemis) makes t very probable that this graffito names Anteros, the son of Ares and Aphrodite.

127) A.G. WOODHEAD, The calendar of the year 304/3 B.C. in Athens, in Hesperia, 58 (1989), p. 297-301: W. relates the intercalation of one month in 304/3 BC in Athens [in Horos 4 (1986), p. 19-23] with the initiation of King Demetrios in the Eleusinian Mysteries (PLuT., Demetr., 26). In order to make Demetrios' initiation possible, the month Mounichion was identified with Anthesterion and recieved the name Anthesterion; as soon as Demetrios' initiation was carried out, Mounichion received the name Boedromion. W. restores in this inscription Anthesterion II; this month took the place of Anthesterion in the natural sequence of months, but was called Anthesterion II since Mounichion had already received the name Anthesterion I. W. also gives a list of calendar equations between the conciliar and the "festival" year in 304/3. 
128) F.C. WOUDHUIZEN, The recently discovered Greek-Sidetic bilinguae from Seleucia, in Talanta, 20/21 (1988/89), p. 87-96 [SEG 38, 1433]: W. discusses the Greek-Sidetic dedication of Euempolos (Seleukeia in Pamphyalia; C. B RIXHE - G. NeUmanN, in Kadmos, 27, 1988, 35-43). According to

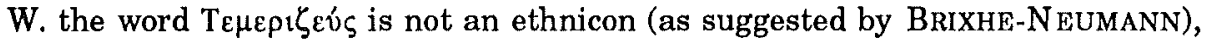
since the place name Temeriza is not attested. He relates this word to $\theta \varepsilon \dot{\mu \varepsilon} \rho{ }^{2} v=$

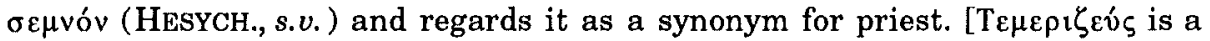
perfectly normal ethnicon, in contrast to the adventurous derivation from $\theta \varepsilon$ é with a suffix -iza. Temeriza would not be the first new place name we learn from new inscriptions].

\section{Corrigenda to EBGR 1988}

P. 267, read: soul: 32.124 .171 .179

$N^{\circ} 23$ (end), read: infra (117)

$N^{\circ} 124$ (end), read: supra (1 32)

$\mathrm{N}^{\circ} 167$ (end), read: $E B G R$ 197, 45

Seminar für Alte Geschichte

Angelos CHANIOTIS

Marstallhof 4

6900 Heidelberg 